\title{
The Bunger Hills: 60 years of geological and geophysical research
}

\author{
NAOMI M. TUCKER ${ }^{1}{ }^{1}$, MARTIN HAND ${ }^{2}$ and CHRIS CLARK ${ }^{3}$ \\ ${ }^{1}$ School of Earth Sciences, University of Western Australia, Perth, 6009, Australia \\ ${ }^{2}$ Department of Earth Science, University of Adelaide, Adelaide, 5000, Australia \\ ${ }^{3}$ Department of Applied Geology, Curtin University, Perth, 6102, Australia \\ naomi.tucker@uwa.edu.au
}

\begin{abstract}
Correlation of Rodinian and Gondwanan crustal domains relies on a thorough knowledge of those vestiges preserved today. The Bunger Hills hold a critical place in East Antarctica, recording the Mesoproterozoic assembly of Australo-Antarctica in Rodinia and the Neoproterozoic-Cambrian amalgamation of Indo- and Australo-Antarctica in Gondwana. It is situated in a region of disputed overlap between the different components of Rodinia and Gondwana, where there is little consensus on the location of sutures in this region and thus often speculative geological interpretations. The Bunger Hills therefore provide an opportunity to better understand the tectonic setting and palaeogeography during the assembly of these supercontinents. Recent work has confirmed that the Bunger Hills are one of few rare outcrops in Wilkes Land, East Antarctica that can be directly correlated with the broader Musgrave-Albany-Fraser-Wilkes Orogen (MAFWO). Whilst other constituent terranes of the MAFWO have been intensely studied, our geological knowledge of the Bunger Hills was comparatively limited until recently. In light of recent geological and geophysical developments, this contribution serves as an updated and concise standalone reference for the present state of knowledge of the Neoarchean-Cambrian evolution of the Bunger Hills region.
\end{abstract}

Received 9 May 2019, accepted 13 September 2019

Key words: Bunger Hills, East Antarctica, Gondwana, Musgrave-Albany-Fraser-Wilkes Orogen, Rodinia

\section{Introduction}

The Bunger Hills, islands and peninsulas immediately to the north (collectively, Highjump Archipelago (HJA)) and several nunataks within the Denman Glacier (Figs 1 $\& 2$ ), are of fundamental importance in understanding the tectonic evolution of the Precambrian East Antarctic Craton, yet they occur within one of the least understood geological regions on Earth. Geophysical interpretations place this region within the Bunger Hills Block, which is characterized by a series of aligned high-intensity magnetic anomalies (Aitken et al. 2014). Magnetic intensity and gravity anomaly data reflect a continuity of major geophysical features between south-west Australia and Wilkes Land in East Antarctica (Aitken et al. 2014, 2016). By accounting for significant offset along these geological structures, intercontinental stitching points are invoked between the two continents in Rodinian and Gondwanan palaeogeographical reconstructions, although the exact pre-breakup alignment of Australia and East Antarctica is a topic of debate (White et al. 2013 and references therein, Aitken et al. 2016, Halpin et al. 2017, Daczko et al. 2018, Williams et al. 2018). Recent geochronological and isotopic work (Tucker et al. 2017) and evidence for a comparable high-grade Mesoproterozoic metamorphic evolution
(Harris 1995, Fitzsimons 2000, 2003, Tucker \& Hand 2016, Tucker et al. 2018) reconcile the Bunger Hills with the west Albany-Fraser Orogen in south-west Australia. Ultimately, the Bunger Hills are located in a critical position within this region of disputed overlap between the different suggested palaeogeographical fits and close to a critical piercing point during supercontinent assembly and breakup (Fig. 1).

The first geological observations of the Bunger Hills were documented by Ravich et al. (1968), who provided a largely petrological account of samples collected during the 1956-1957 Soviet Antarctic Expedition. A subsequent expedition in 1986 provided detailed structural, lithological and geochemical observations (Stüwe \& Powell 1989, Sheraton et al. 1990, 1992, 1993, 1995, Stüwe \& Wilson 1990, Ding \& James 1991) and reconnaissance geochronological and metamorphic data. These data provided the first indication of a broad geological connection between the Bunger Hills and south-west Australia since the Mesoproterozoic (Clarke et al. 1995, Harris 1995, Sheraton et al. 1995, Fitzsimons 2000, 2003). These early field and petrographic observations, geochronological and geochemical data and tectonic interpretations were recently complemented by a third field campaign (2014-2015) primarily to investigate the crustal evolution of the Bunger Hills 


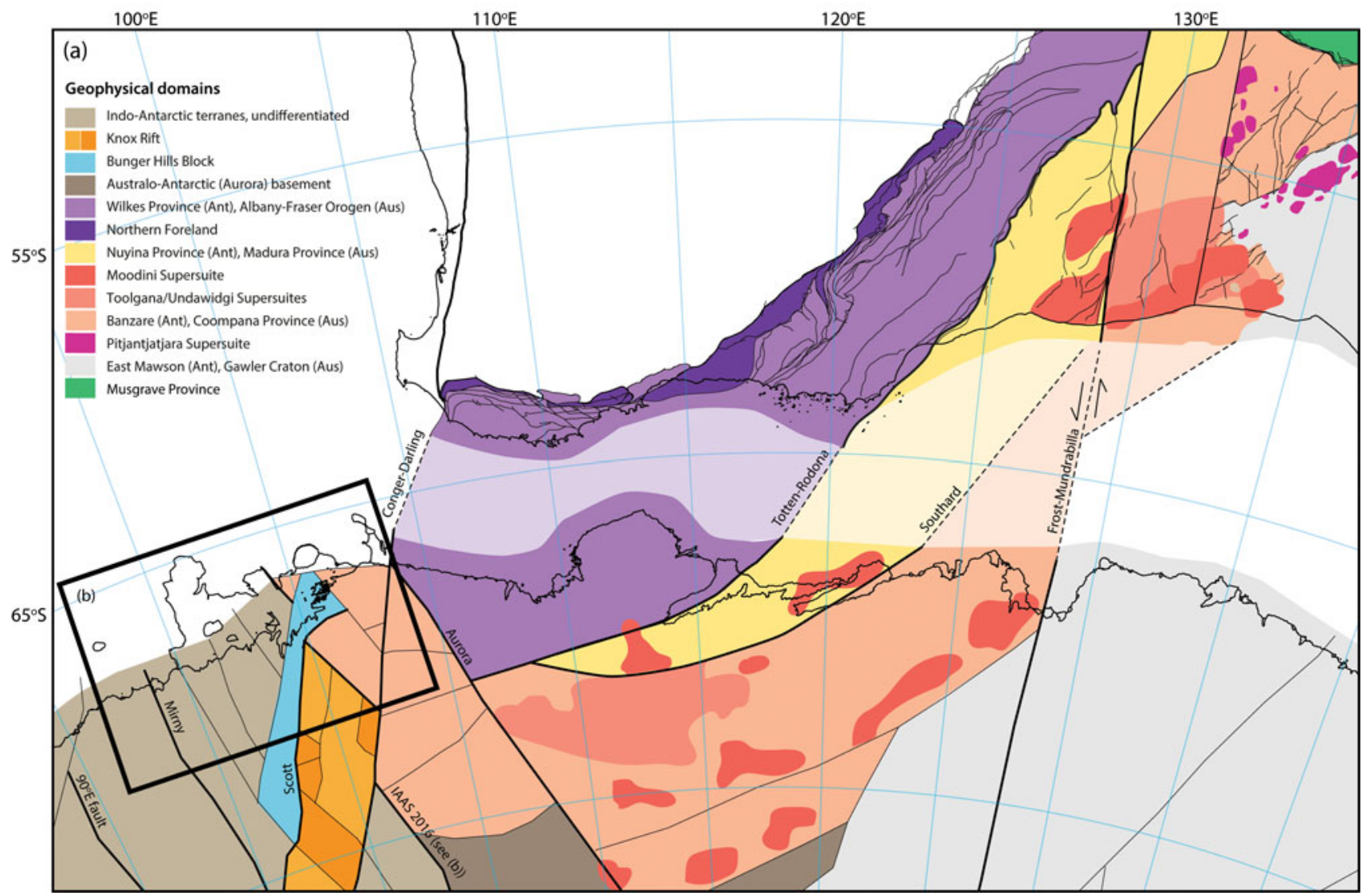

Fig. 1. a. Reconstruction of conjugate Proterozoic tectonic provinces of south-west Australia and Wilkes Land, East Antarctica. The reconstruction is shown for $c .160 \mathrm{Ma}$ (pre-Gondwana breakup), for which there are robust full-fit models, and was generated with GPlates (v. 2.1) using the Leeuwin model of Williams et al. (2011) with Antarctica fixed in its present-day reference frame (datum WGS84). Major structures are shown as bold lines and are labelled. The boxed region is enlarged in b. Australian tectonic elements and Archean-Mesoproterozoic structures are adapted from Western Australia and South Australia state-wide geospatial datasets (State of Western Australia, Department of Mines and Industry Regulation and Safety 2019: https:/dasc. dmp.wa.gov.au/dasc; Geological Survey of South Australia online database (South Australian Resources Information Gateway, SARIG): https://map.sarig.sa.gov.au), and geophysical interpretations for the Moodini, Toolgana and Undawidgi Supersuites are from Maritati et al. (2019). East Antarctic tectonic elements and geophysical lineaments are from Aitken et al. (2014) and the updated interpretations of Maritati et al. (2016, 2019). b. Simplified map of Wilkes Land and Queen Mary Land. Spatial data, including rock outcrop and moraine extent (pink shading), and the Landsat Image Mosaic of Antarctica (United States Geological Survey, USGS) are from various sources collated in the Quantarctica spatial dataset (Norwegian Polar Institute: https:/quantarctica.npolar.no). Summarized isotopic constraints for outcrops in these regions are shown as yellow circles (refer to Table I). The coastline is outlined in yellow. The location of the Bunger Hills (enlarged in Fig. 2) is indicated. Grid references refer to the present-day geographical location of Antarctica. Different interpretations of the locations of major crustal boundaries are shown as solid and dashed bold lines and labelled (from Aitken et al. 2014, Gardner et al. 2015, Maritati et al. 2016, Daczko et al. 2018). Thin black lines represent other geophysical lineaments from Maritati et al. (2016).

(Tucker et al. 2017) and its metamorphic evolution (Tucker \& Hand 2016, Tucker et al. 2018), mafic dyke petrogenesis (Stark et al. 2018) and palaeomagnetism (Liu et al. 2018). These new investigations have been aided by geophysical work on the subglacial geology of Wilkes Land (Aitken et al. 2014, 2016, Maritati et al. 2016, 2019) and isotopic studies on legacy samples from the Bunger Hills region and Wilkes Land coastal exposures (Daczko et al. 2018, Mulder et al. 2019).
These recent additions warrant a review of existing geological data and tectonic interpretations of the Bunger Hills region.

Accordingly, this contribution presents a concise, updated account of the subglacial geology of the Bunger Hills and immediate areas. It integrates published geological data from all field seasons at the time of writing and serves as a standalone reference for the present state of knowledge of the geological evolution of 


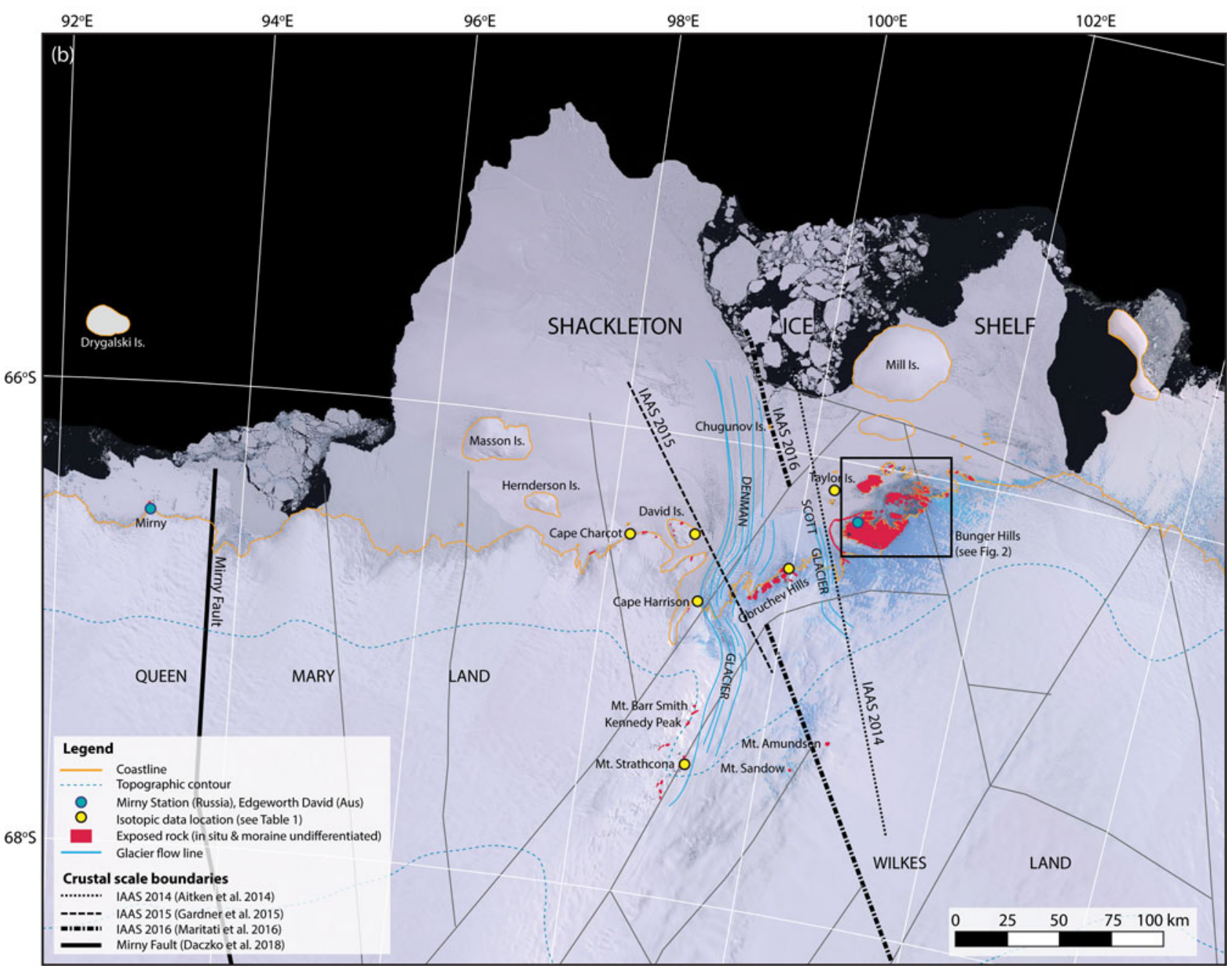

Fig. 1. Continued.

the Bunger Hills region and its geological connection with other parts of East Antarctica and south-west Australia.

\section{Lithological framework}

The Bunger Hills region comprises primarily granulite facies rocks with igneous and sedimentary protoliths, voluminous weakly deformed gabbro-granite and mafic dykes (Fig. 3). Sheraton et al. (1995) and Ravich et al. (1968) provided detailed accounts of the major lithologies and their mineralogies and whole-rock geochemical data for the igneous rocks. Tucker et al. (2018) refined the main lithologies into five subdivisions by age and spatial distribution. Field relations and geochronological and isotopic data show that the Bunger Hills comprise: 1) a Neoarchean basement (Association 1; Fig. 3a, b \& d), 2) a Palaeo-Mesoproterozoic sequence of interlayered orthogneiss-pelite gneiss (Associations 2 and 3; Fig. 3e \& f) and migmatitic pelite gneiss (Association 4; Fig. 3g-i), 3) Mesoproterozoic plutonic rocks (Association 5; Fig. 3j
\& k), and 4) several chemically distinct mafic dyke suites that intruded between $c . \geq 1140$ and $500 \mathrm{Ma}$ (collectively denoted Association 6 in this contribution; Fig. 31). A summary of all existing isotope and age data from the Bunger Hills region is provided in Table I.

\section{Neoarchean basement (Association 1)}

The south-eastern part of the Bunger Hills is dominated by tonalite-dolerite orthogneiss and lesser migmatitic garnet-cordierite-orthopyroxene-spinel-sapphirine gneiss with voluminous orthopyroxene-bearing leucosomes. These rocks have inferred $c$. 2800-2700 Ma protolith emplacement and depositional ages, respectively (Tucker et al. 2017). The metasedimentary rocks appear to form a large ( $20 \mathrm{~m}$ long) enclave within the mafic-felsic gneiss, but lithological contacts in this region are largely obscured, with further exploration required to elucidate the lithological relationships. However, broad similarities are observed between the morphology, age and isotopic 
Table I. Summarized age and isotopic data from the Bunger Hills and surrounding areas.

\begin{tabular}{|c|c|c|c|c|c|c|c|}
\hline Sample & Locality & Lithology (Association) & Age (Ma) & Interpretation & Isotopic data & Measure & References \\
\hline 86285893 & Cape Charcot & Tonalite orthogneiss & $\begin{array}{l}3003 \pm 8^{\mathrm{a} *} \\
2889 \pm 9^{\mathrm{a} *}\end{array}$ & $\begin{array}{l}\text { Emplacement } \\
\text { ?Metamorphism }\end{array}$ & & & $\begin{array}{l}\text { Black et al. (1992) } \\
\text { Black et al. (1992) }\end{array}$ \\
\hline BH67 & SE Bunger Hills & Tonalite-granodiorite orthogneiss (1) & $2712 \pm 27^{\mathrm{a} *}$ & Emplacement & $\begin{array}{l}1.7 \pm 0.8 \\
5.8 \pm 0.45\end{array}$ & $\begin{array}{l}\varepsilon_{\mathrm{Hf}}(\mathrm{t}) \\
\delta^{18} \mathrm{O}\end{array}$ & $\begin{array}{l}\text { Tucker et al. (2017) } \\
\text { Tucker et al. (2017) }\end{array}$ \\
\hline BH68 & SE Bunger Hills & Diorite orthogneiss (1) & $2763 \pm 40^{\mathrm{a} *}$ & & $-1.5 \pm 0.7$ & $\varepsilon_{\mathrm{Hf}}(\mathrm{t})$ & Tucker et al. (2017) \\
\hline BH62 & SE Bunger Hills & Migmatitic g-cd-opx-sa gneiss (1) & $2710 \pm 20^{\mathrm{a} *}$ & Inheritance & $\begin{array}{l}3.0 \pm 6.0 \\
4.77 \pm 0.11\end{array}$ & $\begin{array}{l}\varepsilon_{\mathrm{Hf}}(\mathrm{t}) \\
\delta^{18} \mathrm{O}\end{array}$ & $\begin{array}{l}\text { Tucker et al. (2017) } \\
\text { Tucker et al. (2017) }\end{array}$ \\
\hline 86285807 & NE Obruchev Hills & Tonalite orthogneiss & $\begin{array}{l}2692 \pm 12^{\mathrm{a} *} \\
2641 \pm 15^{\mathrm{a} *}\end{array}$ & $\begin{array}{l}\text { Emplacement } \\
\text { ?Emplacement }\end{array}$ & 22.9 & $\varepsilon_{\mathrm{Nd}}(1160)$ & $\begin{array}{l}\text { Daczko et al. }(2018) \\
\text { Sheraton et al. }(1992,1995)\end{array}$ \\
\hline BH95 & S Bunger Hills & Migmatitic g-cd-sp-opx gneiss (2) & Palaeoproterozoic ${ }^{\wedge}$ & ?Inheritance & $\begin{array}{l}2.3 \pm 0.6 \\
4.47 \pm 0.36\end{array}$ & $\begin{array}{l}\varepsilon_{\mathrm{Hf}}(1885) \\
\delta^{18} \mathrm{O}\end{array}$ & $\begin{array}{l}\text { Tucker et al. (2017) } \\
\text { Tucker et al. (2017) }\end{array}$ \\
\hline 86285960 & SW Bunger Hills & Granodiorite orthogneiss & $1699 \pm 15^{\mathrm{a} *}$ & Emplacement & -9.6 & $\varepsilon_{\mathrm{Nd}}(1160)$ & Sheraton et al. $(1992,1995)$ \\
\hline BH79 & NE Bunger Hills & Tonalite gneiss (3) & $1666 \pm 49^{\mathrm{a} *}$ & Emplacement & $\begin{array}{l}-1.7 \pm 0.6 \\
7.39 \pm 0.08\end{array}$ & $\begin{array}{l}\varepsilon_{\mathrm{Hf}}(\mathrm{t}) \\
\delta^{18} \mathrm{O}\end{array}$ & $\begin{array}{l}\text { Tucker et al. (2017) } \\
\text { Tucker } \text { et al. (2017) }\end{array}$ \\
\hline BH12 & Near Edgeworth David & Tonalite gneiss (2) & $1750-1650^{\mathrm{a} \wedge}$ & Emplacement & $\begin{array}{l}-2.2 \pm 0.6 \\
6.75 \pm 0.29\end{array}$ & $\begin{array}{l}\varepsilon_{\mathrm{Hf}}(\mathrm{t}) \\
\delta^{18} \mathrm{O}\end{array}$ & $\begin{array}{l}\text { Tucker et al. (2017) } \\
\text { Tucker et al. (2017) }\end{array}$ \\
\hline 86285628 & Thomas Island & Granodiorite orthogneiss & $1521 \pm 29^{\text {a: }}$ & ?Emplacement $/ \mathrm{Pb}$ loss & -7.5 & $\varepsilon_{\mathrm{Nd}}(1160)$ & Sheraton et al. $(1992,1995)$ \\
\hline BH54 & Central Bunger Hills & Migmatitic g-cd-opx-sp gneiss (4) & $\begin{array}{l}\text { Neoarchean- } \\
\text { Palaeoproterozoic } \\
1490 \pm 27^{\mathrm{a}}\end{array}$ & $\begin{array}{l}\text { Inheritance } \\
\text { ?Max. depositional }\end{array}$ & & & $\begin{array}{l}\text { Tucker et al. (2017) } \\
\text { Tucker et al. (2017) }\end{array}$ \\
\hline BH95 & S Bunger Hills & Migmatitic g-cd-sp-opx gneiss (2) & $1300-1200^{\mathrm{a} \wedge}$ & Metamorphism & -10 to -9.5 & $\begin{array}{l}\varepsilon_{\mathrm{Hf}}(\mathrm{t})(\mathrm{two} \\
\text { analyses })\end{array}$ & Tucker et al. (2017) \\
\hline $\mathrm{BH} 74$ & NE Bunger Hills & g-cd-sill gneiss (4) & $\begin{array}{l}1295-1186^{\mathrm{a} \wedge} \\
1254-1142^{\mathrm{c}}\end{array}$ & Metamorphism and $\mathrm{Pb}$ loss & & & Tucker et al. (2018) \\
\hline BH100 & SW Bunger Hills & Tonalite orthogneiss (2) & $1256 \pm 5^{\mathrm{a}}$ & Emplacement & $\begin{array}{l}-6.9 \pm 0.6 \\
8.09 \pm 0.07\end{array}$ & $\begin{array}{l}\varepsilon_{\mathrm{Hf}}(\mathrm{t}) \\
\delta^{18} \mathrm{O}\end{array}$ & $\begin{array}{l}\text { Tucker et al. (2017) } \\
\text { Tucker } \text { et al. (2017) }\end{array}$ \\
\hline BH54 & Central Bunger Hills & Migmatitic g-cd-opx-sp gneiss (4) & $\begin{array}{l}1256-1143^{\mathrm{c} \wedge} \\
1268-1201^{\mathrm{a}}\end{array}$ & Metamorphism and $\mathrm{Pb}$ loss & & & Tucker et al. $(2017,2018)$ \\
\hline BH44 & Central Bunger Hills & g-cd-mt-sp gneiss (4) & $1260-1122^{\mathrm{c} \wedge}$ & Metamorphism and $\mathrm{Pb}$ loss & & & Tucker et al. (2018) \\
\hline BH67 & SE Bunger Hills & Tonalite-granodiorite orthogneiss (1) & $1245 \pm 19^{\text {at }}$ & Metamorphism & & & Tucker et al. (2017) \\
\hline $\mathrm{BH} 20$ & Central Bunger Hills & g-cd-sill-bi-mt gneiss (4) & $1245-1157^{\mathrm{c} \wedge}$ & Metamorphism & & & Tucker et al. (2018) \\
\hline BH48 & Central Bunger Hills & g-cd-mt-sp gneiss (4) & $1241-1087^{\mathrm{c} \wedge}$ & Metamorphism $/ \mathrm{Pb}$ loss & & & Tucker et al. (2018) \\
\hline BH32 & NW Bunger Hills & g-cd-sill gneiss (4) & $\begin{array}{l}1220-1144^{\mathrm{c} \wedge} \\
1235-1192^{\mathrm{a} \wedge}\end{array}$ & Metamorphism/ $\mathrm{Pb}$ loss & & & Tucker et al. (2018) \\
\hline BH62 & SE Bunger Hills & Migmatitic g-cd-opx-sa gneiss (1) & $1221 \pm 37^{\mathrm{at}}$ & Metamorphism & & & Tucker et al. (2017) \\
\hline
\end{tabular}




\begin{tabular}{|c|c|c|c|c|c|c|c|}
\hline $\begin{array}{l}\text { Collective } \\
\text { samples }\end{array}$ & All Bunger Hills & Group 3A dolerites & $1220 \pm 80^{\mathrm{b}}$ & Emplacement & & & Sheraton et al. (1995) \\
\hline BH98 & SW Bunger Hills & $\begin{array}{l}\text { Migmatitic enderbite } \\
\text { (5, Algae Lake Pluton) }\end{array}$ & $1203 \pm 5^{\mathrm{a}}$ & Emplacement & $\begin{array}{l}-9.7 \pm 0.4 \\
8.59 \pm 0.08\end{array}$ & $\begin{array}{l}\varepsilon_{H f}(t) \\
\delta^{18} \mathrm{O}\end{array}$ & $\begin{array}{l}\text { Tucker et al. (2017) } \\
\text { Tucker } \text { et al. (2017) }\end{array}$ \\
\hline BH38 & Geologov Island & $\begin{array}{l}\text { Migmatitic enderbite } \\
\text { (5, Paz Cove Batholith) }\end{array}$ & $1200 \pm 6^{\mathrm{a}}$ & Emplacement & $\begin{array}{l}-10.8 \pm 0.5 \\
8.67 \pm 0.09\end{array}$ & $\begin{array}{l}\varepsilon_{H f}(t) \\
\delta^{18} O\end{array}$ & $\begin{array}{l}\text { Tucker et al. (2017) } \\
\text { Tucker } \text { et al. (2017) }\end{array}$ \\
\hline $\mathrm{BH} 23$ & Central Bunger Hills & $\mathrm{g}$-cd-bi-mt-sp gneiss & $1195-1153^{\mathrm{c}^{\wedge}}$ & Metamorphism/Pb loss & & & Tucker et al. (2018) \\
\hline 86286006 & Cape Harrison & Granite gneiss & $1192 \pm 83^{\mathrm{a} *}$ & ?Emplacement & & & Daczko et al. (2018) \\
\hline 86285628 & Thomas Island & Granodiorite orthogneiss & $\begin{array}{c}1190 \pm 15^{\text {a }} \text { (population } \\
\text { indistinct from other } \\
\text { analyses) }\end{array}$ & ?Metamorphism/Pb loss & & & Sheraton et al. (1992) \\
\hline 86286264 & North Raketa Island & g-sill-ru gneiss (3) & $1188 \pm 12^{\mathrm{c} *}$ & Metamorphism & & & Tucker \& Hand (2016) \\
\hline 86286251 & Zabyyty Island & g-cd gneiss (3) & $1186 \pm 11^{\mathrm{ct}}$ & Metamorphism & & & Tucker \& Hand (2016) \\
\hline 86285606 & Currituck Is & Metapelite & $1177 \pm 12^{\mathrm{a}}$ & Metamorphism & & & Daczko et al. (2018) \\
\hline 86285962 & SW Bunger Hills & $\begin{array}{l}\text { Quartz monzogabbro } \\
\text { (5, Algae Lake Pluton) }\end{array}$ & $1171 \pm 3^{\mathrm{a}}$ & Emplacement & -9.4 & $\varepsilon_{\mathrm{Nd}}(1170)$ & Sheraton et al. $(1992,1995)$ \\
\hline 86286245 & N Bunger Hills & $\begin{array}{l}\text { Quartz monzogabbro } \\
\text { (5, Paz Cove Batholith) }\end{array}$ & $1170 \pm 4^{\mathrm{a}}$ & Emplacement & & & Sheraton et al. (1992) \\
\hline 86285628 & Thomas Island & Granodiorite orthogneiss & $1166 \pm 8^{\mathrm{a}}$ & Metamorphism & & & Daczko et al. (2018) \\
\hline 86285638 & Thomas Island & Metapelite & $1164 \pm 5^{\mathrm{a}}$ & Metamorphism & & & Daczko et al. (2018) \\
\hline 86285607 & Geografov Island & g-sill-ru gneiss (3) & $1161 \pm 18^{\mathrm{ct}}$ & Metamorphism & & & Tucker \& Hand (2016) \\
\hline 86286001 & Mt. Strathcona & Paragneiss & $1155 \pm 5^{\mathrm{a}}$ & Metamorphism & & & Daczko et al. (2018) \\
\hline 86285815 & Booth Peninsula & $\begin{array}{l}\text { Quartz monzogabbro (5, Booth } \\
\text { Peninsula Batholith) }\end{array}$ & $1151 \pm 4^{\mathrm{a}}$ & Emplacement & -3.5 & $\varepsilon_{\mathrm{Nd}}(1150)$ & Sheraton et al. $(1992,1995)$ \\
\hline 86285807 & NE Obruchev Hills & Tonalite orthogneiss & $1141 \pm 45^{\mathrm{a} * *}$ & ?Metamorphism/Pb loss & & & Daczko et al. (2018) \\
\hline 86286075 & Central Bunger Hills & Group 4B dolerites & Inferred c. 1140 & Emplacement & +3.9 & $\varepsilon_{\mathrm{Nd}}(1140)$ & Sheraton et al. (1995) \\
\hline 86285678 & SW Bunger Hills & Group 1 dolerites & Inferred $>1140$ & Emplacement & -0.7 & $\varepsilon_{\mathrm{Nd}}(1140)$ & Sheraton et al. (1995) \\
\hline BHD1 and D4 & $\begin{array}{l}\text { Near Paz Cove (D1) } \\
\text { and near Algae Lake (D4) }\end{array}$ & Equivalent Group 4B dolerites & $\begin{array}{l}1134 \pm 9^{\mathrm{at}} \\
1131 \pm 16^{\mathrm{ft}}\end{array}$ & $\begin{array}{l}\text { Emplacement } \\
\text { Emplacement }\end{array}$ & $\begin{array}{l}+1.51 \text { to }+3.32 \\
+11.03 \text { to }+15.09\end{array}$ & $\begin{array}{l}\varepsilon_{\mathrm{Nd}}(1130) \\
\varepsilon_{\mathrm{Hf}}(1130)\end{array}$ & Stark et al. (2018) \\
\hline 86285833 & Geomorfologov Peninsula & Group 4D dolerites & $1120 \pm 40^{\mathrm{d}}$ & Emplacement & +2.9 & $\varepsilon_{\mathrm{Nd}}(1140)$ & Sheraton et al. $(1990,1995)$ \\
\hline 86285811 & Mainly Obruchev Hills & Group 4E dolerite dykes & $1110 \pm 160^{\mathrm{b}}$ & Emplacement & +6.3 & $\varepsilon_{\mathrm{Nd}}(1140)$ & Sheraton et al. $(1990,1995)$ \\
\hline 86285807 & NE Obruchev Hills & Tonalite orthogneiss & $1040 \pm 53^{a * *}$ & $\begin{array}{l}\text { ?Pb loss (very poorly } \\
\text { constrained) }\end{array}$ & & & Sheraton et al. $(1992,1995)$ \\
\hline 86285960 & SW Bunger Hills & Granodiorite orthogneiss & $990^{\mathrm{a} * *}$ & $\begin{array}{l}\text { ?Pb loss (very poorly } \\
\text { constrained) }\end{array}$ & & & Sheraton et al. $(1992,1995)$ \\
\hline Collective & All Bunger Hills & Group 2 high-Mg dolerite dykes & $645 \pm 121^{\mathrm{b}}$ & Isotopic resetting & & & Sheraton et al. $(1990,1995)$ \\
\hline
\end{tabular}




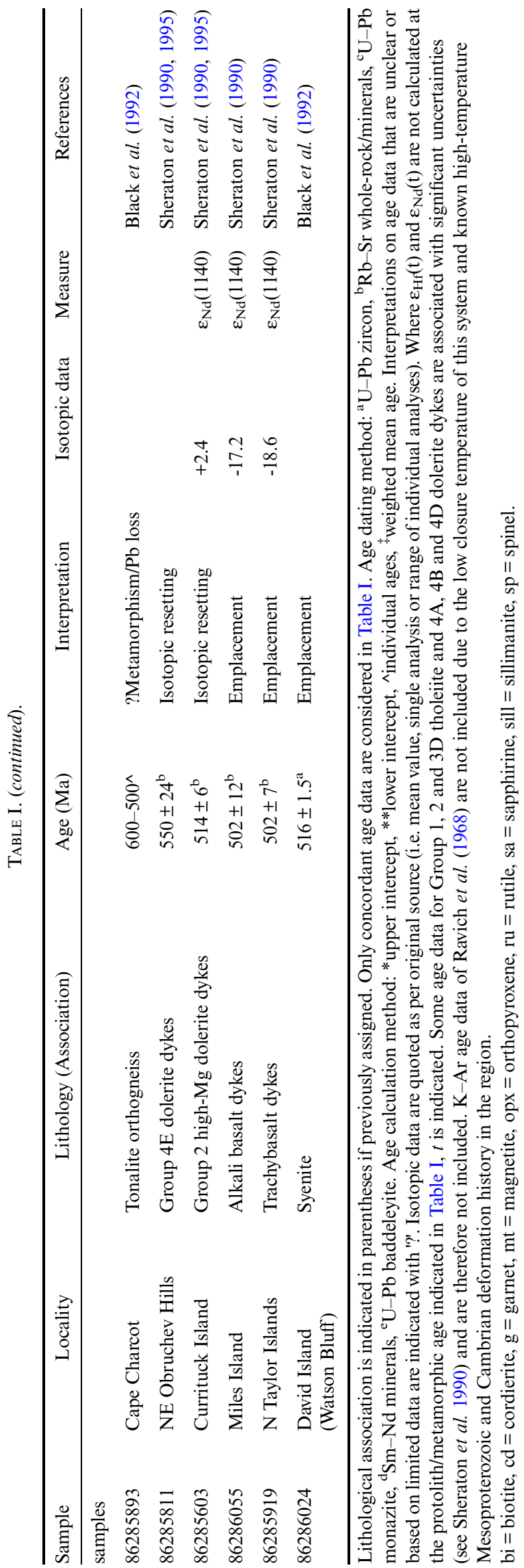

composition of the Neoarchean zircon from the maficfelsic orthogneiss $\left(\varepsilon_{\mathrm{Hf}}(\mathrm{t})=-4.2\right.$ to $+5.1 ; \delta^{18} \mathrm{O}=+5.2$ to $+6.4)$ and those from the pelite $\left(\varepsilon_{\mathrm{Hf}}(\mathrm{t})=+0.6\right.$ to +5.7 ; $\delta^{18} \mathrm{O}=+4.5$ to +5.7 ), suggesting that the latter were sourced from the igneous rocks (Tucker et al. 2017).

\section{Palaeo-Mesoproterozoic gneissic sequence (Associations 2-4)}

A sample of garnet-cordierite gneiss from the southcentral Bunger Hills (sample BH95; near the contact between Association 1 and 2) yielded a dominant c. 1900-1800 Ma zircon population and a discordant array of dates to $c .1520 \mathrm{Ma}$ (Tucker et al. 2017). Zircon from this sample was isotopically juvenile (mean $\varepsilon_{\mathrm{Hf}}(\mathrm{t})$ $=+2.3$; mean $\delta^{18} \mathrm{O}=+4.5$; Tucker et al. 2017). Owing to ancient $\mathrm{Pb}$ loss and a lack of additional samples exhibiting comparable zircon spectra, the significance of this rock remains unclear. It is plausible that the rock has a mid-Palaeoproterozoic protolith, but the zircon subsequently underwent $\mathrm{Pb}$ loss. Alternatively, the rock may be dominated by mid-Palaeoproterozoic detritus and have a possible Mesoproterozoic maximum depositional age (Tucker et al. 2017).

The Neoarchean tonalite-dolerite orthogneiss becomes increasingly felsic (tonalite-granite) and interlayered with mafic granulite and metasedimentary rocks (all Association 2) towards the north-west (Fig. 2; Sheraton et al. 1995, Tucker et al. 2017). The central Bunger Hills comprise a regularly interlayered sequence (centimetre to metre scale) of garnet-cordierite \pm sillimanite gneiss and orthopyroxene \pm garnet \pm hornblende tonalite-granitic orthogneiss, with lesser quartzofeldspathic gneiss, mafic granulite, garnet \pm biotite granitic gneiss and rare calc-silicate (Association 3; Sheraton et al. 1995, Tucker et al. 2017). Reconnaissance U-Pb zircon geochronology on an Y-depleted, I-type granodiorite and orthopyroxenequartzofeldspathic orthogneiss suggested that the protoliths to these rocks from the south-west Bunger Hills and Thomas Island (both inferred Association 2) were emplaced at $1699 \pm 15$ and $1521 \pm 29 \mathrm{Ma}$, respectively (Sheraton et al. 1992). These rocks yielded isotopically evolved $\varepsilon_{\mathrm{Nd}}(\mathrm{t})$ values of -9.6 and -7.5 , respectively (Sheraton et al. 1995). Recent U-Pb geochronology from orthopyroxene-bearing tonalite orthogneiss in the west Bunger Hills (Association 2) and tonalitic orthogneiss interlayered with metasedimentary rocks in the north-east Bunger Hills (Association 3) yielded imprecise inferred crystallization ages of $c$. 1750-1650 Ma (sample BH79) and $1666 \pm 49 \mathrm{Ma}$ (sample BH12), respectively (Tucker et al. 2017). These rocks yielded $\varepsilon_{\mathrm{Hf}}(\mathrm{t})$ and $\delta^{18} \mathrm{O}$ values of +1.3 to -6.3 ( $\mathrm{t}$ as the upper intercept age of discord due to $\mathrm{Pb}$ loss) and +6.8 to +7.9 , and +1.3 to -4.8 and +5.4 to +7.9 , respectively (Tucker et al. 2017). These new age and isotopic constraints are broadly consistent with those 


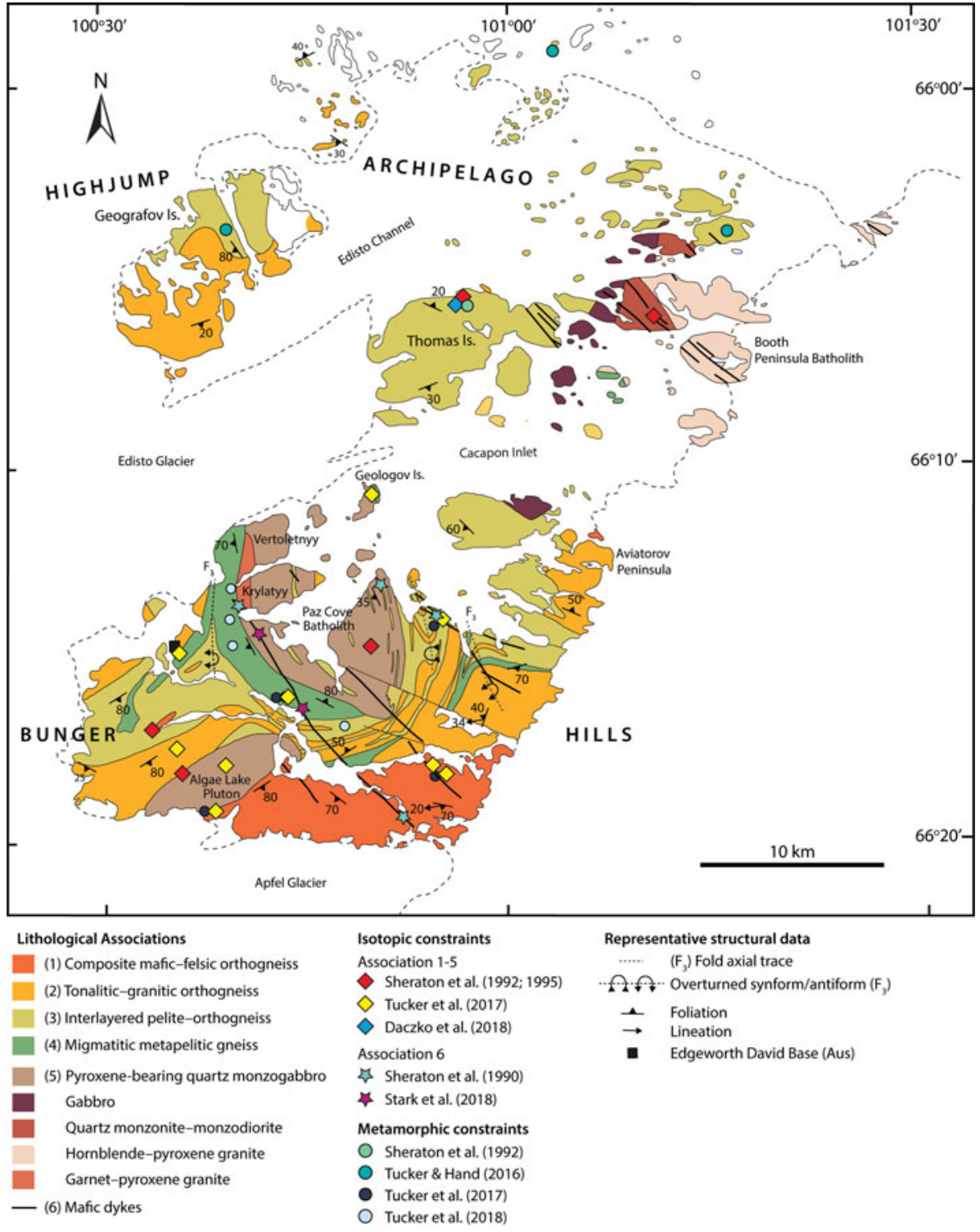

Fig. 2. Simplified geological map of the Bunger Hills and Highjump Archipelago (after Tucker et al. 2018). The location of isotopic and age data and metamorphic constraints from Tucker \& Hand (2016) and Tucker et al. (2018) are shown (see also Table I). Representative structural data from Sheraton et al. (1995) are overlain. obtained previously from the same lithological sequence (i.e. Sheraton et al. 1992). Rocky outcrops within the HJA are inferred to largely comprise Associations 2 and 3 based on field observations (Fig. 2).

The northern Bunger Hills are dominated by a thick sequence of migmatitic garnet-cordierite \pm sillimanite \pm orthopyroxene \pm spinel \pm magnetite-bearing gneiss and minor quartzite and psammite (Association 4; Fig. 2). Sheraton et al. (1995) noted that the rocks are strongly migmatized adjacent to the Paz Cove in the central Bunger Hills and that the migmatitic gneisses in this region are dominated by cordierite. Tucker et al. (2018) support this observation, noting the presence of cordierite-bearing leucosomes (Fig. 3h). Elsewhere in the central Bunger Hills, the migmatitic gneisses are dominated by orthopyroxene, with coarse-grained orthopyroxene-bearing leucosomes (Fig. 3i; e.g. sample BH54; Tucker et al. 2017,
2018). Sheraton et al. (1995) note that, in places, spinel is rimmed by coronae of garnet, cordierite or sillimanite. The sedimentary protoliths to Association 4 contain abundant $c$. 1800-1600 Ma detritus and minor zircon ages between c. 2200 and $1800 \mathrm{Ma}$ and c. 3000 and $2500 \mathrm{Ma}$ (Tucker et al. 2017). These rocks are interpreted to have been deposited during the Mesoproterozoic, after c. 1700 Ma magmatism but prior to the onset of magmatism and metamorphism during the Albany-Fraser Orogeny (see below), with a probable maximum depositional age of c. $1490 \mathrm{Ma}$ (Tucker et al. 2017). This age is based on the youngest concordant analysis of an oscillatory-zoned (inferred detrital) zircon core; however, the integrated trace element and geochronological approach of Tucker et al. (2018) highlighted that zircon morphology alone may be a deceptive indicator of metamorphic $v s$ detrital zircon. Many ages from zircon initially inferred to be metamorphic 

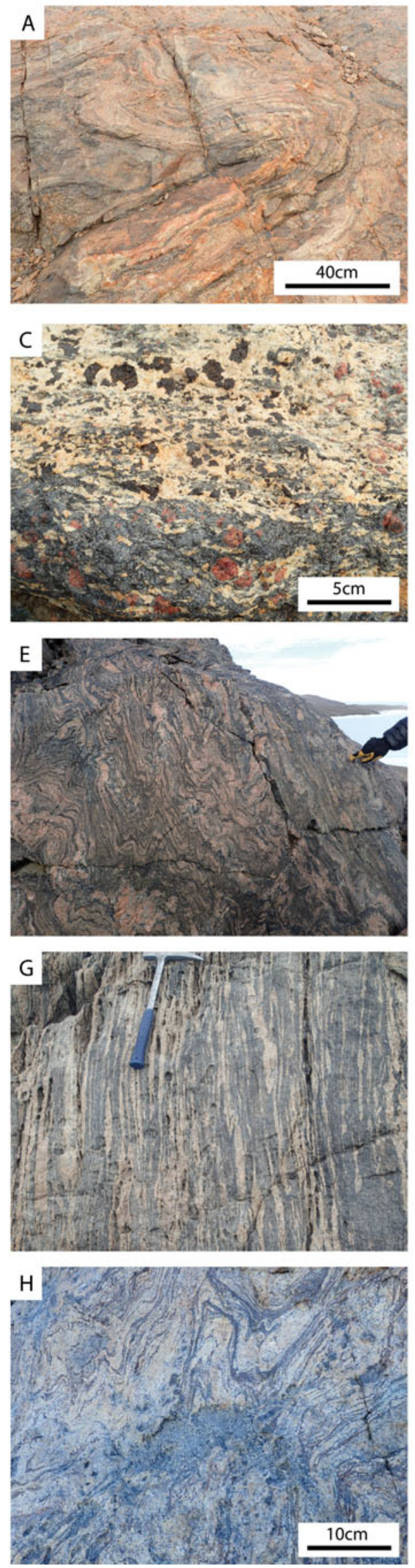
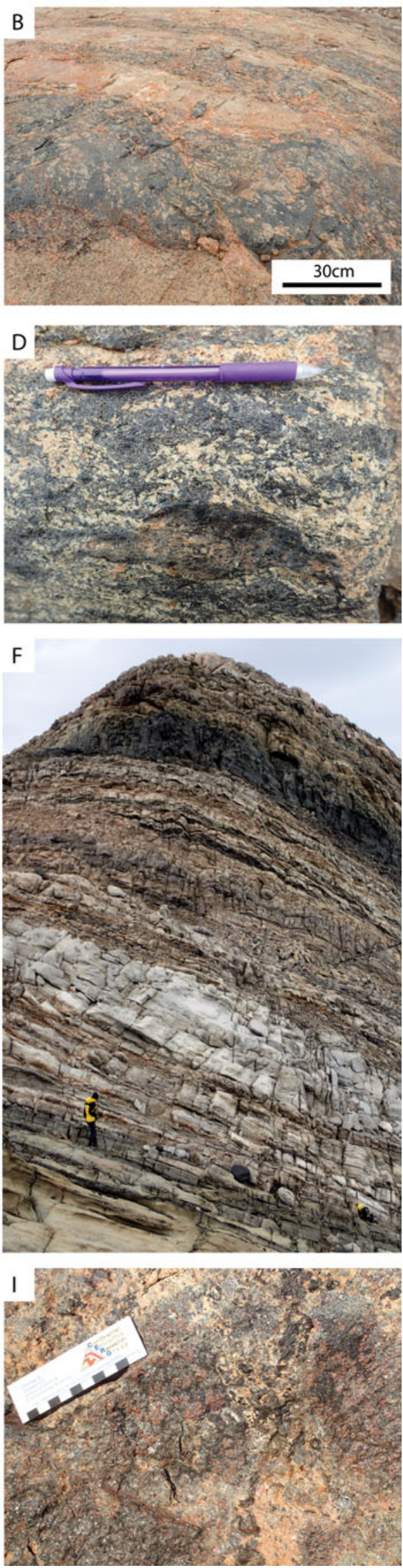

Fig. 3. Typical outcrop appearance and lithological relationships of rocks in the Bunger Hills. a. Mafic and felsic orthogneiss, south-east Bunger Hills (Association 1). b. Garnet-cordieriteorthopyroxene gneiss (dark layers) with voluminous orthopyroxene-bearing leucosomes (light layers) hosted within maficfelsic orthogneiss in the south-east Bunger Hills (Association 1). c. Garnet-cordierite-orthopyroxene gneiss within the moraine, similar in appearance to b. d. Sapphirinespinel-orthopyroxene-plagioclase \pm garnet gneiss near the location of b. e. Typical appearance of tonalitediorite gneiss comprising Association 2 near Edgeworth David base. f. Regularly interlayered sequence of metasedimentary rocks, tonalite gneiss, minor mafic gneiss, quartzite and pssamite in the north-east Bunger Hills (Association 3). g. Typical appearance of migmatitic garnetcordierite \pm sillimanite \pm orthopyroxene \pm biotite \pm magnetite gneiss in the central Bunger Hills (Association 4).

h. \& i. Metasedimentary rocks comprising Association 4 are typically cross-cut by (h.) late cordierite or (i.) orthopyroxene leucosomes, depending on bulk composition. j. Lithological contact between granite (Paz Cove Batholith, left, Association 5) and metasedimentary rocks (Association 4) on Krylatyy Peninsula. k. Weakly deformed plutonic rocks of Paz Cove Batholith are interlayered with Association 4 at their margins. l. Mafic dyke cross-cutting all other lithological associations. Photograph taken near Paz Cove.

m.--o. Representative photographs of sedimentary (conglomerate and arkose sandstone) and igneous (rapakivi granite) moraine. 

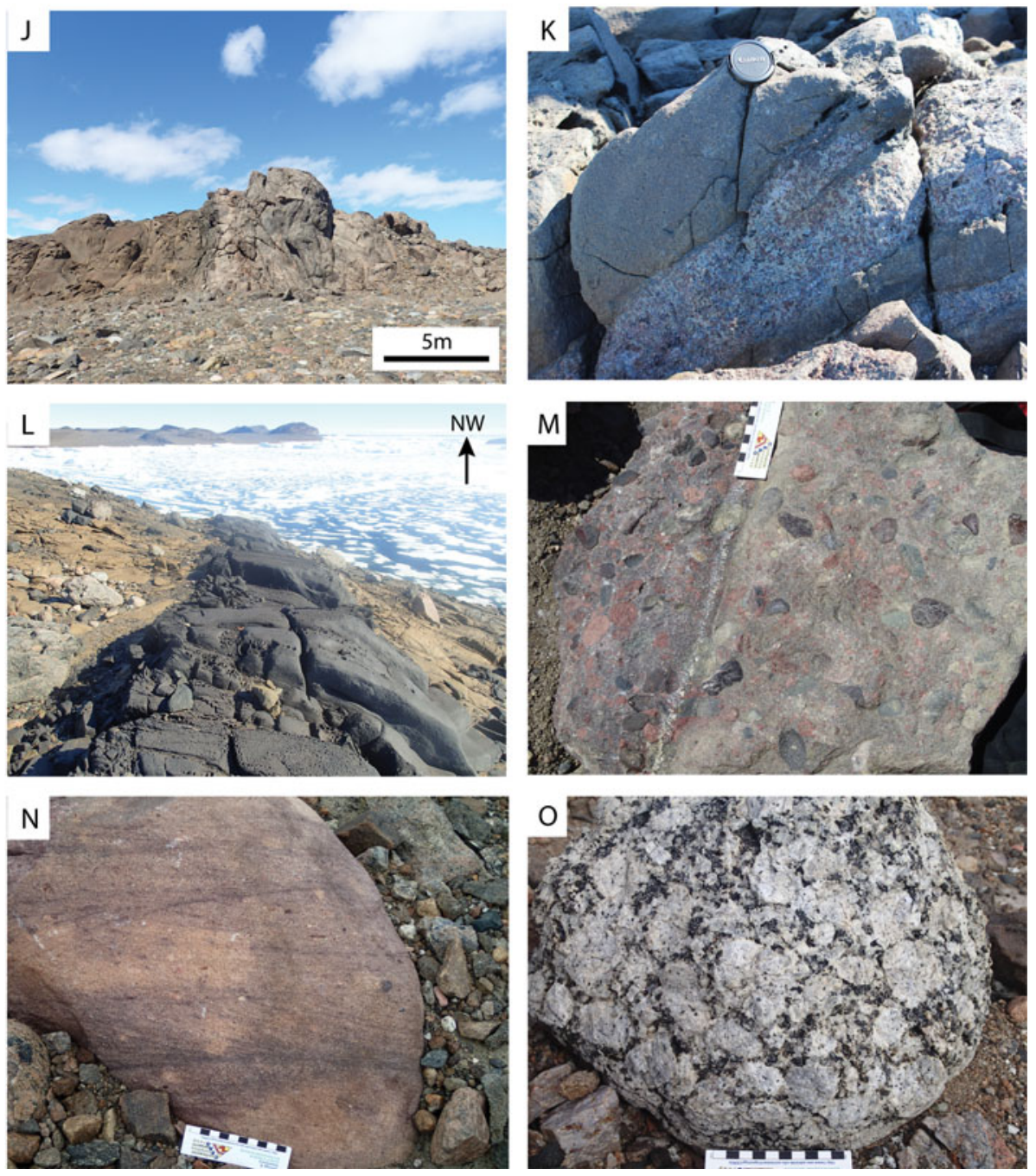

Fig. 3. Continued.

were subsequently reinterpreted as reflecting isotopic resetting, meaning that the maximum depositional age of this sequence is loosely constrained and potentially younger. The minimum depositional age is constrained by intrusion of the Paz Cove Batholith (c. 1200-1170 Ma) that is observed interlayered with and hosting enclaves of Association 4 on Geologov Island (Fig. 3k; see below; Sheraton et al. 1995, Tucker et al. 2017).

A sample of biotite-orthopyroxene-rich tonalitegranodiorite gneiss, $\sim 5 \mathrm{~km}$ west of the Algae Lake Pluton (BH100; Fig. 2), yielded an inferred protolith age of $1256 \pm 5 \mathrm{Ma}$ (Tucker et al. 2017). This sample is located within a region denoted as Association 2 and is interlayered with garnet-sillimanite gneiss, but it is significantly younger than all other rocks presently analysed from this sequence. The protolith emplacement age of this rock and its isotopically evolved composition $\left(\varepsilon_{\mathrm{Hf}}(\mathrm{t})=-4.6\right.$ to $-11.4 ; \delta^{18} \mathrm{O}=+7.4$ to +8.4 ; Tucker et al. 2017) are similar, however, to the Mesoproterozoic plutonic rocks in the Bunger Hills, although the later were clearly emplaced during the late stages of deformation, as they are weakly deformed or undeformed.

\section{Weakly deformed Mesoproterozoic plutonic rocks (Association 5)}

Three large (up to $\sim 10 \mathrm{~km}$ in diameter) intrusive bodies crop out in the Bunger Hills (together Association 5; Fig. 1). Field observations indicate that the intrusive bodies contain orthopyroxene, minor clinopyroxene, biotite and hornblende and are mineralogically and lithologically heterogeneous at the outcrop scale (10-100 m; Sheraton et al. 1992, 1995, Tucker et al. 2017). The Paz Cove Batholith and Algae Lake Pluton contain orthopyroxene-bearing leucosomes that both align with and cross-cut a weak fabric that is defined by the alignment of orthopyroxene and plagioclase. Sheraton et al. $(1992,1995)$ noted that the Algae Lake Pluton and Paz Cove Batholith are petrographically similar, ranging geochemically between gabbro and 
quartz monzogabbro, although granite also crops out in the latter on the Vertoletnyy and Krylatyy peninsulas (Fig. 2). The Booth Peninsular Batholith is larger, more compositionally varied and contains significantly more gabbro and quartz-gabbro than the other two intrusive bodies (Fig. 2; Sheraton et al. 1995). The different lithological domains within each intrusive body locally exhibit cross-cutting and intrusive relationships (Sheraton et al. 1992, 1995, Tucker et al. 2017). Sheraton et al. (1995) note that on the Booth Peninsula the felsic lithologies appear to postdate the mafic lithologies, though locally they grade into one another. In places, the intrusive rocks clearly cross-cut and host enclaves of, or are interlayered with, the surrounding gneissic country rocks (e.g. Geologov Island; Tucker et al. 2017).

Reconnaissance $\mathrm{U}-\mathrm{Pb}$ zircon geochronology suggested that the Algae Lake Pluton, Paz Cove Batholith and Booth Peninsula Batholith (formerly Lake Figure and Fishtail Gulf plutons and the Charnockite Peninsula Batholith; Sheraton et al. 1992) were emplaced at $1171 \pm 3$, $1170 \pm 4$ and $1151 \pm 4 \mathrm{Ma}$, respectively (Sheraton et al. 1995). These ages are younger than those obtained by Tucker et al. (2017), who suggested that the Algae Lake Pluton and Paz Cove Batholith were emplaced at $1203 \pm 5$ and $1200 \pm 5 \mathrm{Ma}$, respectively. Tucker et al. (2017) reported a large spread in isotopically evolved zircon compositions $\left(\varepsilon_{\mathrm{Hf}}(\mathrm{t})=-13\right.$ to -6$)$ and positive $\delta^{18} \mathrm{O}$ values $(+8.3$ to +9.2$)$ for the Paz Cove Batholith and Algae Lake Pluton. These isotopic data are consistent with data obtained previously from the Algae Lake Pluton $\left(\varepsilon_{\mathrm{Nd}}(\mathrm{t})=\right.$-9.4; Sheraton et al. 1992), revealing the highly evolved nature of the protolith to these rocks. Sheraton et al. (1992) obtained a slightly more isotopically juvenile $\varepsilon_{\mathrm{Nd}}(\mathrm{t})$ value of -3.5 for the Booth Peninsular Batholith, which is consistent with the higher proportion of mafic rocks in this region.

The lithological heterogeneity and significant variation in age and isotopic compositions of the Paz Cove Batholith and Algae Lake Pluton (Sheraton et al. 1992, 1995, Tucker et al. 2017) suggest that they are composite intrusive bodies (i.e. comprising a cluster of multiple smaller intrusions). It is probable that Mesoproterozoic magmatism in the Bunger Hills occurred episodically between c. 1200 and $1170 \mathrm{Ma}$ (Tucker et al. 2017). A similar explanation was proposed by Zhang et al. (2012) to reconcile differences in the protolith ages obtained for Mesoproterozoic plutonic rocks in the Windmill Islands, $\sim 400 \mathrm{~km}$ east of the Bunger Hills (1205 and $1196 \mathrm{Ma}$; Post 2000, Zhang et al. 2012).

\section{Mafic dykes (Association 6)}

The Bunger Hills are dissected by abundant doleritebasalt dykes. Field observations and whole-rock $\mathrm{Rb}-\mathrm{Sr}$ and $\mathrm{Sm}-\mathrm{Nd}$ geochronological data suggest that they intruded between $c . \geq 1140$ and $500 \mathrm{Ma}$ (Sheraton et al. 1990, 1993, 1995). The dykes can be subdivided into an older generation of deformed and metamorphosed olivine-tholeiites and quartz-tholeiites within the plutonic bodies and mafic granulite layers within the basement gneisses and a series of younger undeformed dykes that cross-cut the basement rocks and plutonic bodies (Sheraton et al. 1990, 1992, 1993, 1995). The latter have an inferred maximum emplacement age of c. $1203 \mathrm{Ma}$, which is the crystallization age of the plutonic rocks that are intruded by the dykes (Tucker et al. 2017). As the current age constraints on the plutons are disparate (i.e. compare the ages obtained by Tucker et al. 2017 and Sheraton et al. 1992), there is a high degree of uncertainty on this maximum emplacement age.

Geochemistry and field relations indicate that the undeformed dykes comprise five compositionally distinct groups (olivine-tholeiites, weakly alkaline dolerites, picrites-ankaramites, alkali basalts and trachybasalts; Sheraton et al. 1990, 1995, Stark et al. 2018). Group 1 dykes are tholeiitic, $<2 \mathrm{~m}$ wide and largely restricted to the south-west Bunger Hills (Sheraton et al. 1990, 1995). Group 2 dykes are north-west-trending, high-Mg dolerites of variable thickness. Group 3 and 4 dykes are the most abundant of all the dykes in the Bunger Hills, commonly trend NW-SE, comprise dolerite and range up to $50 \mathrm{~m}$ in width (Sheraton et al. 1990, 1995). Early Rb-Sr and Sm$\mathrm{Nd}$ isochron ages suggested that the Group 2-4 dykes were emplaced at c. $1140 \mathrm{Ma}$, but this estimate was based on imprecise data and isochrons inferred to reflect partial resetting at $c .500 \mathrm{Ma}$ (Sheraton et al. 1990, 1995). Stark et al. (2018) provided the first U-Pb zircon and baddeleyite age data for the largest mafic dyke in the Bunger Hills (equivalent to Group 4B dykes of Sheraton et al. 1990), constraining its emplacement age to $1134 \pm 9$ and $1131 \pm 16 \mathrm{Ma}$ by the two methods, respectively. These new age data suggest that other similarly orientated dykes in the Bunger Hills (i.e. Group 3 and 4) are coeval, but further investigation is required. The Group 5 dykes comprise alkali basalts and trachybasalts from the west Bunger Hills and Taylor Islands. These dykes are E-W trending, typically $<1 \mathrm{~m}$ wide and have an inferred emplacement age of $502 \mathrm{Ma}$ based on $\mathrm{Rb}-\mathrm{Sr}$ whole-rock geochronology (Sheraton et al. 1990).

\section{Structural geology}

The Bunger Hills have experienced at least three major phases of deformation at high temperature during the Palaeo-Mesoproterozoic (Table II; Stüwe \& Wilson 1990, Ding \& James 1991, Sheraton et al. 1993, 1995, Harris 1995, Tucker et al. 2017). Several structural models have been proposed to contextualize the different phases of Mesoproterozoic deformation and metamorphism (see 
Table II. Summarized interpretations of the Mesoproterozoic structural and metamorphic evolution of the Bunger Hills.

\begin{tabular}{|c|c|c|c|c|}
\hline & Stüwe \& Wilson (1990) & Ding \& James (1991) & Sheraton et al. $(1993,1995)$ & Tucker et al. $(2017,2018)$ \\
\hline $\mathrm{D}_{1}$ & $\begin{array}{l}\text { Crustal extension } \\
\left.\text { Emplacement of mafic dykes (pre-early } \mathrm{D}_{1}\right) \\
\text { Variable boudinage of mafic layers } \\
\mathrm{S}_{1} \text { fabric development } \\
\text { Localized mesoscopic } \mathrm{F}_{1} \text { isoclinal and } \\
\text { recumbent folding ( } \mathrm{S} \text { verging) } \\
\text { Peak granulite facies metamorphism } \\
\left(\mathrm{M}_{1} ; 800^{\circ} \mathrm{C}, 4 \mathrm{kbar}\right) \\
\text { Syn- } \mathrm{D}_{1} \text { emplacement of Paz Cove Batholith }\end{array}$ & $\begin{array}{l}S_{1} \text { fabric development parallel to } \\
\text { compositional layering } \\
\text { Mesoscale } F_{1} \text { isoclinal and sheath folding } \\
\text { Granulite facies metamorphism }\end{array}$ & $\begin{array}{l}\mathrm{S}_{1} \text { fabric development parallel to compositional } \\
\left.\text { layering (axial planar to } \mathrm{F}_{1}\right) \\
\text { Mesoscopic } \mathrm{F}_{1} \text { intrafolial folding } \\
\text { Granulite facies metamorphism }\left(\mathrm{M}_{1} ; 750-800^{\circ} \mathrm{C} \text {, }\right. \\
5-6 \text { kbar; } c .1190 \mathrm{Ma}) \\
\text { Late-post } \mathrm{D}_{1} \text { emplacement of mafic dykes }\end{array}$ & $\begin{array}{l}S_{1} \text { fabric development } \\
\text { Mesoscopic } F_{1} \text { folding }\end{array}$ \\
\hline $\mathrm{D}_{2}$ & $\begin{array}{l}N E-S W \text { shortening } \\
\text { Pre-early } \mathrm{D}_{2} \text { emplacement of mafic dykes } \\
\text { Regional, meso-macroscale } \mathrm{F}_{2} \text { folding } \\
\text { (NE verging, variable axial plane orientation) } \\
\text { Granulite facies metamorphism } \\
\left(\mathrm{M}_{2} ; 750^{\circ} \mathrm{C}, 6.5 \mathrm{kbar}\right) \\
\text { Late-post- } \mathrm{D}_{2} \text { emplacement of Algae } \\
\text { Lake Pluton }\end{array}$ & $\begin{array}{l}N W \text {-SE shortening } \\
\text { Regional, meso-macroscale isoclinal } \mathrm{F}_{2} \\
\text { folding (shallow } \mathrm{SW} \text { plunge) } \\
\text { Tight-recumbent parasitic folding } \\
\text { (SW-NE-trending hinges) }\end{array}$ & $\begin{array}{l}\text { Shortening? } \\
\text { Regional, mesoscopic } \mathrm{F}_{2} \text { folding } \\
\text { (tight-isoclinal, asymmetric and recumbent-reclined, } \\
\left.\text { presently variable orientations due to } \mathrm{F}_{3}\right) \\
\text { Granulite facies metamorphism }\left(\mathrm{M}_{2}\right)\end{array}$ & $\begin{array}{l}\text { Regional, mesoscopic } F_{2} \text { folding } \\
\text { (tight-isoclinal, reclined-recumbent) } \\
\text { Pervasive } S_{2} \text { fabric development coplanar } \\
\text { with } S_{1} \\
\text { Peak granulite facies metamorphism syn- } \mathrm{D}_{1} / \mathrm{D}_{2} \\
\left(5.5-7.1 \mathrm{kbar}, 800-960^{\circ} \mathrm{C} ; \text { c. } 1220-1180 \mathrm{Ma}\right)\end{array}$ \\
\hline $\mathrm{D}_{3}$ & $\begin{array}{l}\text { Regional late } \mathrm{D}_{3} \text { doming } \\
\text { Variable reorientation of } \mathrm{D}_{2} \text { structures } \\
\text { Emplacement of mafic dykes } \\
\text { (syn- } \mathrm{D}_{3} \text { deformation) } \\
\text { Amphibolite facies metamorphism }\end{array}$ & $\begin{array}{l}N N W-S S E \text { to } N W-S E \text { shortening } \\
\text { Regional, macroscale, tight, upright } \mathrm{F}_{3} \text { folding } \\
\text { Development of two major antiforms } \\
\text { (originally } \sim \mathrm{E}-\mathrm{W} \text {-trending axial planes) } \\
\text { Reorientation/folding of } \mathrm{D}_{2} \text { structures }\end{array}$ & $\begin{array}{l}N N W-S S E \text { shortening (c. } 1170 \mathrm{Ma} \text { ) } \\
\text { Regional, macroscale, upright, asymmetric } \\
\mathrm{F}_{3} \text { folding (variable orientation due } \\
\text { to pluton emplacement) } \\
\text { Reorientation/folding of } \mathrm{D}_{1} \text { and } \mathrm{D}_{2} \text { structures } \\
\text { Granulite facies metamorphism }\left(\mathrm{M}_{3}\right) \\
\text { Syn- } \mathrm{D}_{3} \text { emplacement of Paz Cove Batholith and } \\
\text { Algae Lake Pluton }\end{array}$ & $\begin{array}{l}\text { Open, upright, meso-macroscale } F_{3} \text { folding } \\
\text { (typically NW-SE trending) } \\
\text { Reorientation of } D_{1} \text { and } D_{2} \text { structures } \\
\text { and steepening of earlier } S_{1}-S_{2} \text { fabrics } \\
\text { Emplacement of Paz Cove Batholith and } \\
\text { Algae Lake Pluton (late-post- } D_{3} \text { deformation) } \\
\text { Cordierite- and orthopyroxene-bearing partial } \\
\text { melts parallel and cross-cut } F_{3} \text { fold hinges (late } \\
\text { post-pre- } D_{4} \text { ) }\end{array}$ \\
\hline Post-D 3 & & $\begin{array}{l}N N W \text {-directed shortening } \\
\text { Development of major }(2 \mathrm{~km} \text {-wide) thrust } \\
\text { system (WSW-ENE trending) } \\
\text { Amphibolite facies retrogression along shear zones } \\
\text { Emplacement of mafic dykes } \\
\text { Emplacement of Algae Lake Pluton and Paz } \\
\text { Cove and Booth Peninsula batholiths }\end{array}$ & $\begin{array}{l}\text { Emplacement of Booth Peninsula Batholith } \\
\text { (c. } 1150 \mathrm{Ma} \text { ) and syn-plutonic mafic } \\
\text { (dolerite) dykes }\end{array}$ & \\
\hline $\mathrm{D}_{4}$ & $\begin{array}{l}\text { Brittle deformation } \\
\text { Development of shear zones and } \\
\text { mylonite/pseudotachylite } \\
\text { Retrograde metamorphism within } \\
\text { shear zones } \\
\text { Emplacement of mafic dykes }\end{array}$ & $\begin{array}{l}\text { WSW-ENE shortening } \\
\text { Regional, ductile } \mathrm{D}_{4} \text { folding (N-NNW- } \\
\text { trending, W-WSW-dipping axial planes, } \\
\text { two major antiforms and one synform) } \\
\text { Folding of thrust system }\left(\mathrm{D}_{3}\right) \\
\text { Charnockite intrusion }\end{array}$ & $\begin{array}{l}\text { Brittle deformation }(c .1150-1140 \mathrm{Ma} \text { ) } \\
\text { Development of mylonite/ pseudotachylite } \\
\text { and shear zones with dextral offset } \\
\text { (two sets, pre-syn mafic dyke emplacement) } \\
\text { Emplacement of NW-trending mafic dykes } \\
\text { Emplacement of pegmatites }\end{array}$ & $\begin{array}{l}\text { Emplacement of (generally) NW-trending } \\
\text { mafic dykes } \\
\text { Possible mesoscale kink folding of } \mathrm{S}_{3} \text { fabrics }\end{array}$ \\
\hline Post-D 4 & & $\begin{array}{l}\text { Development of mylonite and shear zones } \\
\text { with dextral offset (two sets, WNW and NW } \\
\text { striking) } \\
\text { Emplacement of mafic (alkaline, trachyte) dykes }\end{array}$ & Emplacement of mafic (dolerite) dykes & \\
\hline
\end{tabular}

ent of mafic (alkaline, trachyte) dykes 
Table II). These models largely disagree on the timing of magmatism relative to deformation (see Harris 1995, Sheraton et al. 1995); however, the deformation sequence proposed by Sheraton et al. (1995), who reconcile earlier structural observations (i.e. Stüwe \& Wilson 1990, Ding \& James 1991) with geochronology, and the updated metamorphic interpretations of Tucker et al. $(2017,2018)$ appear to best describe the tectono-metamorphic evolution of the Bunger Hills area. A brief description of the currently accepted structural framework of the Bunger Hills is summarized below, but the reader is referred to the publications above for a more in-depth understanding.

The oldest recognizable tectonic fabric is a pervasive, gentle to moderately dipping composite gneissic fabric $\left(S_{1}-S_{2}\right.$ of Sheraton et al. 1995, Tucker et al. 2017) defined by K-feldspar-rich leucosomes that alternate with $\mathrm{Mg}-\mathrm{Fe}-\mathrm{Al}$-rich melanosome, and within the melanosome by the alignment of sillimanite-biotite + garnet + cordierite + magnetite (Tucker et al. 2018). Mesoscopic structures in the Bunger Hills largely relate to the second phase of deformation $\left(\mathrm{D}_{2}\right)$, but the intensity of $D_{2}$ is variable. The $S_{1}$ fabric is locally preserved by the alignment of sillimanite and biotite within mesoscale $F_{2}$ fold hinges, perpendicular to the strong $\mathrm{S}_{2}$ axial planar fabric, which is also defined by the alignment of these minerals (Tucker et al. 2017, 2018). Stüwe and Wilson (1990) attributed the layer-parallel $S_{1}$ fabric to flattening from crustal extension. The $\mathrm{F}_{2}$ folds are typically tight-isoclinal and reclined-recumbent in orientation, lie in the plane of the $\mathrm{S}_{1}-\mathrm{S}_{2}$ fabric and have shallow SSW-dipping axial planes. $\mathrm{L}_{2}$ is south-dipping and best observed in the north-east and central parts of the Bunger Hills.

The third phase of deformation $\left(\mathrm{D}_{3}\right)$ resulted in open, upright meso-macroscale folding of the earlier fabrics, transposing them into steep orientations. The $F_{3}$ folds are typically NW-SE trending and have steep SE-SW-dipping axial planes and shallow south plunges. East to north-east of the Paz Cove Batholith, the $\mathrm{F}_{3}$ folds are near recumbent and strongly SE-verging, and the $\mathrm{S}_{3}$ fabric is intense and steeply SW-NW dipping, suggesting that this region is a high-intensity $D_{3}$ domain. Elsewhere in the Bunger Hills, $F_{2}$ folds are often sheared by steep $\mathrm{S}_{3}$ shear fabrics (e.g. north of Edgeworth David in the cliff exposure), and $\mathrm{F}_{2}-\mathrm{F}_{3}$ fold interference patterns are also locally observed (e.g. north of Edgeworth David and Thomas Island; Sheraton et al. 1995). Variation in the structural trend of $F_{3}$ folds ( $F_{2}$ folds of Stüwe \& Wilson 1990) has been suggested to result from emplacement of the Algae Lake Pluton and Paz Cove Batholith during the late stages of deformation (pre-syn $\mathrm{D}_{4}$ of Ding \& James 1991, Sheraton et al. 1993, 1995). Late $D_{3}$ emplacement of the plutonic bodies is supported by their weak (inferred) igneous foliation relative to the surrounding gneissic country rocks that they cross-cut and are interleaved with (Ding \& James 1991, Sheraton et al. 1995, Tucker et al. 2017). Sheraton et al. (1993) interpreted the present-day regional structure of the Bunger Hills to primarily reflect $\mathrm{D}_{3}$ NNW-SSE compression.

The Booth Peninsula Batholith on east Thomas Island cross-cuts the $\mathrm{D}_{3}$ structures of Sheraton et al. (1993), suggesting that it was emplaced post- $\mathrm{D}_{3}$ (Sheraton et al. 1995). This interpretation is supported by its younger emplacement age than the Paz Cove Batholith and Algae Lake Pluton, although current interpretations are limited by the low number of analysed samples.

Coarse-grained orthopyroxene-bearing and cordieritebearing leucosomes overprint the reorientated $\mathrm{S}_{1}-\mathrm{S}_{2}$ fabrics and hinges of the $F_{3}$ folds in the migmatitic pelitic gneiss (Tucker et al. 2018). Locally garnet-bearing leucosomes and pegmatites also occur parallel to steeply dipping $\mathrm{F}_{3}$ axial planes and within the hinges of the $\mathrm{F}_{3}$ folds. Previous studies also postulate localized $\mathrm{D}_{4}$ brittle deformation (equivalent to $\mathrm{D}_{3}$ of Stüwe \& Wilson 1990) characterized by multiple generations of retrograde shear zones, pseudotachylite and mylonitic fabrics, pegmatites and mafic dykes, with complex cross-cutting relationships.

\section{Neoarchean-Mesoproterozoic crustal evolution}

The west Albany-Fraser Orogen and Bunger Hills share a similar crustal evolution, with both regions recording evidence of Palaeoproterozoic-early Mesoproterozoic autochthonous reworking of the Yilgarn Craton margin (Fig. 4; Kirkland et al. 2011, 2015, Spaggiari \& Tyler 2014, Smithies et al. 2015b, Spaggiari et al. 2015, Tucker et al. 2017). In contrast, the proposed crustal evolution of the Windmill Islands, which is situated $\sim 400 \mathrm{~km}$ east of the Bunger Hills, diverges from the Bunger Hills and is more strongly linked to accretion of the isotopically juvenile Madura Province on the eastern margin of the Albany-Fraser Orogen (Fig. 4; Spaggiari et al. 2015, Morrissey et al. 2017b). The following description of the Neoarchean-Mesoproterozoic Bunger Hills crustal evolution is compiled from published geochronological, isotopic and geochemical data and highlights the geological links between the Bunger Hills and the Albany-Fraser Orogen.

Tucker et al. (2017) proposed that protoliths to the Neoarchean garnet-sapphirine-orthopyroxene gneiss and mafic-felsic orthogneiss in the Bunger Hills were deposited and emplaced, respectively, within an extensional setting involving volcano-clastic sedimentation. The maficfelsic orthogneiss has age and $\mathrm{Hf}$ isotopic affinity to c. 3000-2600 Ma gneisses, granites and metasedimentary rocks of the Northern Foreland of the Albany-Fraser Orogen, which represents the reworked margin of the Yilgarn Craton, and magmatic rocks from the Yilgarn 


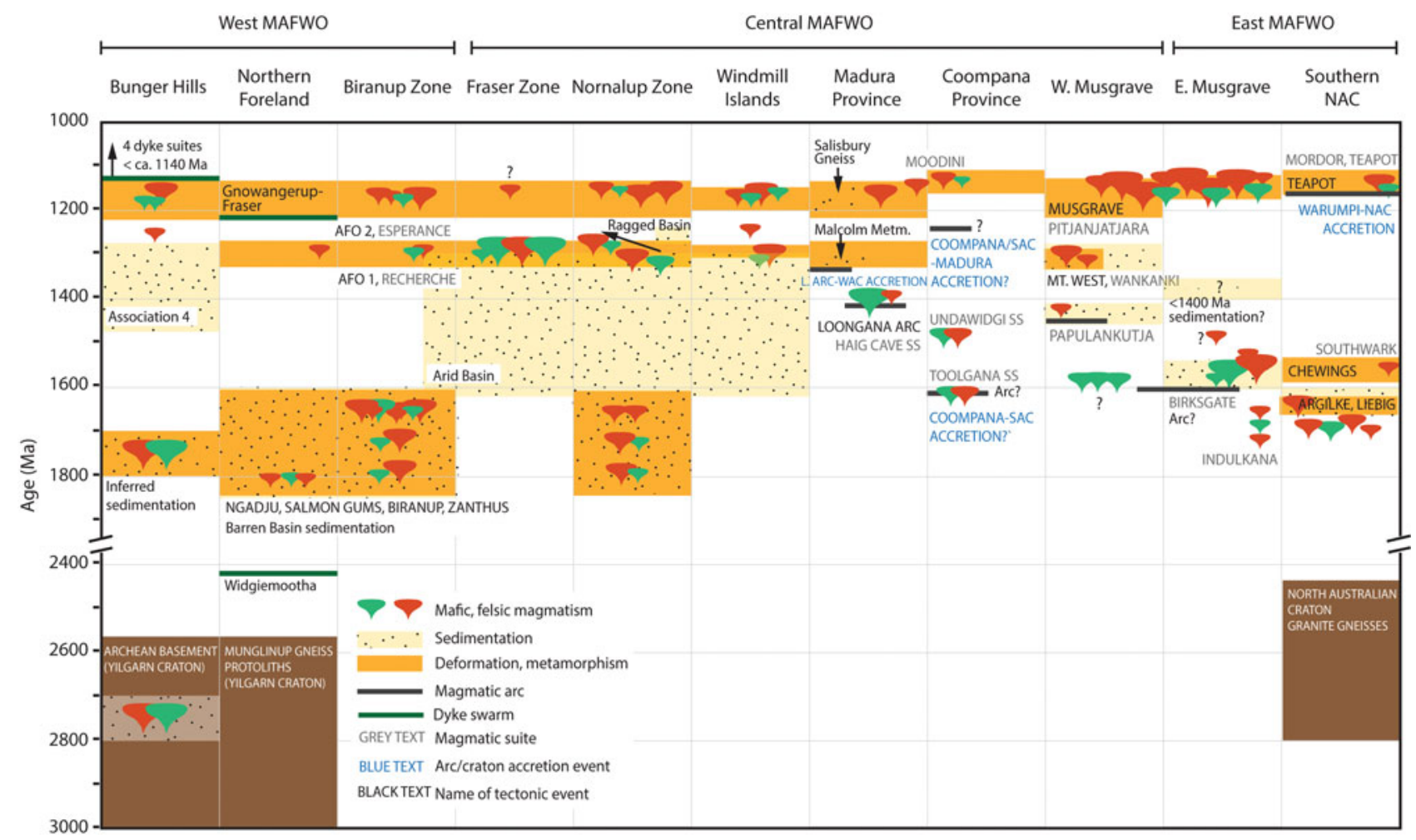

Fig. 4. Time-space comparison of the Archean-Mesoproterozoic crustal evolution of the Bunger Hills region with other constituent terranes of the Musgrave-Albany-Fraser-Wilkes Orogen (MAFWO). Figure adapted from Tucker (2018). $\mathrm{AFO}=$ Albany - Fraser Orogeny, L. Arc $=$ Loongana Arc, NAC = North Australian Craton, SAC = South Australian Craton, SS $=$ supersuite, WAC $=$ West Australian Craton

Craton itself (Kirkland et al. 2015). Although the present dataset limits a robust comparison with the specific terranes of the Yilgarn Craton, the Archean rocks in the Bunger Hills are considered to reflect a rifted, reworked fragment of the Yilgarn Craton margin (Tucker et al. 2017) that experienced a similar Proterozoic crustal evolution to the Northern Foreland (see below; Kirkland et al. 2011, 2015, Spaggiari et al. 2015). The Neoarchean age of the basement rocks comprising Association 1 is broadly consistent with the inferred crystallization age of $2660 \pm 12 \mathrm{Ma}$ tonalite orthogneiss from the Obruchev Hills (Daczko et al. 2018; c. 2640 Ma of Sheraton et al. 1992), although the relationship of the two regions remains unclear because of limited isotopic data to facilitate a robust comparison.

Tucker et al. (2017) suggested that the regular layer-parallel distribution of the orthogneiss and metasedimentary rocks in the central Bunger Hills (Associations 2 and 3) reflected the contemporaneous emplacement of magmas and deposition of sediments during Palaeoproterozoic extension (i.e. within a volcano-sedimentary basin). The Hf isotopic compositions of zircon from the Palaeoproterozoic igneous rocks from the Bunger Hills $\left(\varepsilon_{\mathrm{Hf}}(\mathrm{t})=-6\right.$ to +2 ; Associations 2 and 3; Tucker et al. 2017) fall within the compositional range of those from similarly aged orthogneisses in the Biranup Zone $\left(\varepsilon_{\mathrm{Hf}}(\mathrm{t})=-10\right.$ to +8 ; Kirkland et al. 2011, 2014). Furthermore, the Hf isotopic compositions of the Palaeoproterozoic zircon from both the Bunger Hills and Biranup Zone span a range of $\mathrm{Hf}_{\text {initial }}$ and $\varepsilon_{\mathrm{Hf}}(\mathrm{t})$ values that are more isotopically juvenile than would be expected solely by reworking of the Archean (Yilgarn-like) crust (Tucker et al. 2017). The O isotope compositions of the zircon from the Bunger Hills are suggestive, however, of a crustal component within the parent melt to these rocks, leading Tucker et al. (2017) to conclude that they formed by mixing between a juvenile source at c. $1700 \mathrm{Ma}$ and recycled Archean (Yilgarn) basement rocks.

Based on whole-rock geochemistry, Sheraton et al. (1992) initially suggested that the 1699 Ma Y-depleted granodiorite orthogneiss from the south-west Bunger Hills formed by partial melting of subducted oceanic crust. The $1521 \mathrm{Ma}$ orthogneiss from Thomas Island was interpreted to reflect metamorphic differentiation of the same lithology, supported by inferred metamorphic zircon overgrowths on Palaeoproterozoic zircon cores from this sample (1190 Ma; Sheraton et al. 1992). At present, it is difficult to relate the interpretations of Sheraton et al. (1992) to those of Tucker et al. (2017) 
without more robust isotopic data from the former to better constrain the protolith age and a comprehensive geochemical dataset from the latter. Should a widespread subduction signature in magmatic rocks from Associations 2 and 3 be observed, this may provide support for a back-arc rift setting and thus account for the subduction signature inferred by Sheraton et al. (1992); however, this would contrast with current interpretations for the Biranup Zone, where there is presumed little evidence for Palaeoproterozoic subduction-related magmatism (see below).

The Palaeoproterozoic crustal evolution of the Bunger Hills is considered analogous to that of the Biranup Zone, which involved three phases of Palaeoproterozoic extension and reworking of the Yilgarn Craton margin (1815-1800, 1780-1760 and 1710-1650 Ma; Kirkland et al. 2011, 2014, Spaggiari \& Tyler 2014, Smithies et al. 2015b, Spaggiari et al. 2015), voluminous mantle magmatism during extension (Smithies et al. 2015b) and widespread sedimentation within a series of sub-basins that were cyclically linked with the emplacement, crystallization and erosion of the Palaeoproterozoic magmatic rocks (Spaggiari et al. 2015). Palaeoproterozoic extension was initially proposed to have occurred within a back-arc that formed due to subduction retreat (Kirkland et al. 2011), but was subsequently reinterpreted as occurring in a continental rift, or that the active subduction margin was far-field because of a lack of evidence for subduction-related geochemistry of the igneous rocks (Smithies et al. 2015b), the maturity of the basin sediments and the abundance of Yilgarn Craton detritus (Spaggiari et al. 2015). In the latter scenario, the subduction zone was possibly as distal as the present-day Madura or Coompana provinces (Spaggiari \& Smithies 2015, Spaggiari et al. 2015) and their East Antarctic equivalents.

The significance of the garnet-cordierite gneiss from the south-central Bunger Hills (sample BH95; Association 2) remains unclear. At present, there is little evidence for c. 1900-1800 Ma magmatism in East Antarctica and central and west Australia, meaning that, regardless of the interpretation on the age data, the Palaeoproterozoic zircon was probably sourced from unexposed or now destroyed Palaeoproterozoic basement rocks (Tucker et al. 2017).

One sample of garnet-cordierite gneiss from the central Bunger Hills contains abundant c. 1800-1600 Ma detritus, suggesting that rocks comprising Association 4 were sourced primarily from the Palaeoproterozoic igneous rocks of the Biranup Zone and/or Bunger Hills. Minor age components between c. 2200 and $1800 \mathrm{Ma}$ are suggestive of more far-field sources, such as parts of the northern West Australian Craton, and rare Neoarchean ages are suggestive of a minor contribution from Archean (Yilgarn) basement rocks (Tucker et al. 2017). Deposition was approximately synchronous with sedimentation in the Windmill Islands, east Albany-Fraser Orogen and west Musgrave Inlier (Arid Basin and equivalent; Fig. 4) that occurred between c. 1600 and 1305 Ma (Spaggiari et al. 2015), although their zircon provenance diverges, with the majority of detritus sourced from an oceanic arc (c. 1410 $\mathrm{Ma}$ ) and lesser recycled Palaeoproterozoic basin sediments, and detritus from the Biranup Zone and the Yilgarn Craton (Spaggiari et al. 2015, Morrissey et al. 2017b). Morrissey et al. (2017b) infer a back-arc setting for sediment deposition, whereas Spaggiari et al. (2015) infer a passive margin with sedimentation in a fore-arc to foreland basin. The abundance of ArcheanPalaeoproterozoic detritus and a lack of younger isotopically juvenile zircon in the Bunger Hills metasedimentary rocks suggest that sediment deposition occurred proximal to the craton margin, but further analyses are required to be able to contribute to interpretations surrounding the passive margin $v s$ back-arc models for the Arid Basin and correlatives.

Structural and lithological observations and geochronological data suggest that Mesoproterozoic magmatism in the Bunger Hills occurred during syn-late granulite facies metamorphism (Stüwe \& Wilson 1990, Sheraton et al. 1995, Tucker \& Hand 2016, Tucker et al. 2017). The isotopically evolved nature of the plutonic rocks (Sheraton et al. 1995, Tucker et al. 2017) suggests that their protoliths formed by crustal recycling of Archean crust (i.e. Association 1) mixed with juvenile melts and/or partial melting of the Palaeoproterozoic rocks (i.e. Association 2 and 3) with minor juvenile addition (Tucker et al. 2017). This interpretation is consistent with that based initially on geochemical data that these rocks were derived from an enriched mantle source (Stüwe \& Wilson 1990, Sheraton et al. 1992, 1995). Isotopic data of Sheraton et al. (1992) for the Algae Lake Pluton suggested derivation from a heterogeneous, long-enriched mantle source and that the parent magmas were probably of crustal origin, but whether they entirely reflected subduction-related mantle enrichment processes or were due to more direct crustal contamination was uncertain.

Two-pyroxene, Al-in-amphibole, Ti-in-biotite and clinopyroxene-plagioclase-quartz thermobarometry suggest that the Mesoproterozoic intrusives were emplaced at $800-900^{\circ} \mathrm{C}$ at $5-7 \mathrm{kbar}$ (i.e. $\sim 20 \mathrm{~km}$ depth; Sheraton et al. 1995). These constraints are supported by the presence of pigeonite in granites and quartz monzodiorites from the Paz Cove and Booth Peninsula batholiths, suggesting that crystallization occurred at $>820^{\circ} \mathrm{C}$ at $5 \mathrm{kbar}$ (Sheraton et al. 1995).

Despite recent geochronological studies (e.g. Stark et al. 2018), the overall lack of robust age constraints means that the petrogenesis and tectonic context of each dyke generation in the Bunger Hills remains largely unclear and is an avenue for further work. Trace element and 
isotope geochemistry have suggested that the young dyke generations were derived from at least six different, heterogeneous sources of partially melted mantle (Sheraton et al. 1990). The largest mafic dyke (Group 3-4) is sourced from enriched mid-ocean ridge basalt with an ocean-island basalt-like crustal component; the other dyke generations were probably derived from at least two sources with slightly depleted to moderately enriched compositions (Sheraton et al. 1990, Stark et al. 2018). Stark et al. (2018) suggested that dyke emplacement at c. $1140 \mathrm{Ma}$ occurred due to mafic underplating and was associated with orogenic collapse (i.e. thermal weakening) during the waning stages of high-temperature metamorphism. Stark et al. (2018) also proposed a regional correlation between similarly orientated olivine gabbro dykes in the Windmill Islands, suggesting that a major dyke swarm ( $\sim 400 \mathrm{~km}$ in extent) may have been emplaced due to plume-related activity and mantle interaction with a chemically heterogeneous and variable metasomatized lithosphere.

Liu et al. (2018) recently provided palaeomagnetic data for East Antarctica based on precise age dating of the largest mafic dyke from the Bunger Hills (north-west trending, Group 4), but noted geographical disparity between this palaeopole and two previously measured (and similarly aged) poles from Dronning Maud Land (c. $1130 \mathrm{Ma}$ ) and Coats Land (c. $1100 \mathrm{Ma}$ ). Liu et al. (2018) concluded that these parts of East Antarctica were not rigid terranes at $1134 \mathrm{Ma}$ and were probably unconnected until the final assembly of Gondwana at c. $520 \mathrm{Ma}$, and thus Precambrian continental reconstructions of East Antarctica remain speculative.

\section{High-grade metamorphism}

The Bunger Hills were originally thought to have experienced high-temperature metamorphism at $1190 \pm$ $15 \mathrm{Ma}$ (Sheraton et al. 1992), during $\mathrm{D}_{1}$ deformation (Stüwe \& Powell 1989), based on the age of inferred metamorphic zircon overgrowths from one sample of tonalite orthogneiss from Thomas Island. Daczko et al. (2018) recently re-dated the same sample, obtaining a weighted mean $\mathrm{U}-\mathrm{Pb}$ zircon age of $1166 \pm 8 \mathrm{Ma}$. Zircon geochronology on legacy samples of Sheraton et al. (1995) from the Bunger Hills, HJA and nearby nunataks are consistent with these ages (c. 1180-1165 Ma; Daczko et al. 2018); however, a large in situ monazite and zircon geochronology dataset has suggested that high temperatures were maintained over a significantly longer timeframe (c. 150 Myr; Tucker \& Hand 2016, Tucker et al. 2017, 2018), with peak metamorphism constrained to between c. 1220 and $1180 \mathrm{Ma}$ (Tucker et al. 2018). These new constraints on the timing and duration of high-temperature metamorphism and revised interpretations on the episodic emplacement of Mesoproterozoic magmas over a longer period (see above) are reflective of much more continuous processes than initially thought, challenging the deformation history proposed by previous workers (Table II) that is seemingly rigid, but not rate constrained.

Using forward phase equilibria modelling, Tucker $e t$ al. (2018) and Tucker and Hand (2016) constrained the peak pressure-temperature $(\mathrm{P}-\mathrm{T})$ conditions to 5.5-7.1 kbar at $800-960^{\circ} \mathrm{C}$ from garnet-cordierite \pm sillimanite \pm orthopyroxene \pm magnetite assemblages in the Bunger Hills and 6-9 kbar at $850-950^{\circ} \mathrm{C}$ from garnet \pm sillimanite \pm rutile-bearing assemblages in the HJA. These revised pressure constraints are consistent with those obtained initially by conventional thermobarometry by Stüwe and Powell (1989). These P-T conditions are consistent with the observation that mafic granulite in the north-east Bunger Hills contains garnet (Sheraton et al. 1995). Both the initial and revised peak P-T conditions suggest that the HJA attained slightly higher temperature and pressure conditions than the Bunger Hills (Stüwe \& Powell 1989, Tucker \& Hand 2016, Tucker et al. 2018).

Tucker et al. (2018) considered the peak P-T estimates to relate to the first phase of deformation and formation of the $S_{1}-S_{2}$ fabric. This is because the fabric is defined by the alignment of K-feldspar-rich leucosomes and minerals that are inferred to form part of the peak mineral assemblage within the sillimanite-biotite-garnetcordierite-magnetite-rich melanosome. The $\mathrm{S}_{1}-\mathrm{S}_{2}$ fabric is transposed by tight-isoclinal mesoscale $F_{2}$ folds and steeply reorientated by regional, open, upright $\mathrm{F}_{3}$ folds (see above; Stüwe \& Powell 1989, Sheraton et al. 1995, Tucker et al. 2017). Orthopyroxene- and cordieritebearing leucosomes (Fig. 3h \& i) also overprint the reorientated $\mathrm{S}_{1}-\mathrm{S}_{2}$ fabrics and sometimes align axial planar to $\mathrm{F}_{3}$, providing evidence that high temperatures persisted during the third deformation phase and that the rocks continued to undergo partial melting as pervasive strain declined (Tucker et al. 2018).

Revised interpretations on the microstructural relationships, abundances and compositions of the peak metamorphic minerals suggest that the Bunger Hills and HJA rocks cooled along a post-peak down-temperature to isobaric path (Tucker \& Hand 2016, Tucker et al. 2018). This interpretation is consistent with early observations of garnet forming a symplectitic corona around orthopyroxene in granite from the Paz Cove Batholith and orthogneiss from the north-east HJA (Sheraton et al. 1995). Tucker et al. (2017) observe cordierite and orthopyroxene coronae about garnet and cordierite and plagioclase coronae around sapphirine and spinel in Archean metasedimentary rocks from the south-east Bunger Hills. Orthopyroxene and cordierite also occur within the inferred syn-late- $\mathrm{D}_{3}$ leucosomes, and they are suggestive of low-pressure, high-temperature 
conditions after peak metamorphism; however, their absolute timing and $\mathrm{P}-\mathrm{T}$ conditions are currently unconstrained, as it is unclear what mineral assemblage they existed in equilibrium with, as the $\mathrm{P}-\mathrm{T}$ models are interpreted to relate to $S_{1}-S_{2}$ (Tucker et al. 2018).

\section{Regional Mesoproterozoic correlations}

Rare nunataks and coastal exposures of the East Antarctic basement rocks, immediately west of the Bunger Hills (Fig. 1; Obruchev Hills, Mount Strathcona, Cape Harrison), also record evidence for Mesoproterozoic metamorphic zircon and monazite growth and recrystallization (c. 1190-1140 Ma; Table I; Mikhalsky et al. 2015a, Daczko et al. 2018) and charnockite emplacement (1142 \pm 3.6 Ma, Obruchev Hills; Alexeev et al. 2011). Evidence for Mesoproterozoic hightemperature metamorphism, deformation and magmatism (between $c$. 1345-1260 and/or c. 1220-1130 Ma) is also preserved in the Windmill Islands (Post 2000, Morrissey et al. 2017a), the Albany-Fraser Orogen in south-west Australia (Clark et al. 2000, Smithies et al. 2015b), Madura and Coompana provinces in southern Australia (Spaggiari \& Smithies 2015, Wise et al. 2015, Kirkland et al. 2017) and Warumpi Province, Musgrave Inlier and southern parts of the North Australian Craton in central Australia (Figs 4 \& 5; Morrissey et al. 2011, Smithies et al. 2011, Tucker et al. 2015, Walsh et al. 2015, Wong et al. 2015). This shared high-temperature Mesoproterozoic evolution is broadly attributed to convergence between the North and West Australian cratons and the Mawson Continent (South Australian and Mawson cratons; e.g. Clark et al. 2000, Fitzsimons 2003, Tucker 2018 and references therein).

Magmatism and metamorphism between c. 1345 and $1260 \mathrm{Ma}$ were spatially confined to central parts of the orogen (i.e. the Windmill Islands, eastern parts of the Albany-Fraser Orogen and west Musgrave Inlier; Tucker 2018) and were controlled by the 'soft collision' of an oceanic arc (Spaggiari et al. 2015, 2018) and subsequent generation of a back-arc basin (Morrissey et al. 2017b, Glasson et al. 2019) and/or westward-migrating lower crustal hot zone (Smithies et al. 2015b, Spaggiari et al. 2015). Rocks in the Bunger Hills did not show or were metamorphically unresponsive to deformation and magmatism at this time. The Bunger Hills and Windmill Islands do, however, record minor emplacement of granitic-tonalitic magmas at c. 1260-1215 Ma (Post 2000, Zhang et al. 2012, Morrissey et al. 2017b, Tucker et al. 2017). Magmatism of this age is not recorded in the Australian terranes of the Musgrave-Albany-FraserWilkes Orogen (MAFWO), suggesting that this event was localized or that equivalent magmatism occurred later in the Bunger Hills and Windmill Islands. At present, magmatism of this age in East Antarctica is therefore largely tectonically ambiguous. The Hf isotope compositions of zircon from c. 1260 Ma orthogneiss from the Bunger Hills suggest that the parent magmas to these rocks formed from reworked Yilgarn Craton/Biranup Zone crust (and/or equivalent rocks in the Bunger Hills; see above) with minor mantle addition (Tucker et al. 2017). The c. 1260-1215 Ma granitoids in both the Bunger Hills and Windmill Islands are foliated and deformed by upright folds (Morrissey et al. 2017a, Tucker et al. 2018).

Magmatism and metamorphism between $c .1220$ and $1130 \mathrm{Ma}$ were widespread, occurring within all tectonic regions of the MAFWO (Tucker 2018 and references therein). Magmatism was almost exclusively voluminous felsic-intermediate to charnockitic; however, field evidence for bimodal mafic and felsic magmatism and mafic dyke emplacement is recorded in the Bunger Hills (Sheraton et al. 1990, 1992, 1995). Zircon Hf isotope compositions and whole-rock $\mathrm{Nd}$ isotopes from the felsic plutonic rocks also suggest variable incorporation of a mantle end member source into their parent magmas (Smithies et al. 2011, 2015a, 2015b, Howard et al. 2015, Kirkland et al. 2017, Morrissey et al. 2017b, Tucker et al. 2017). Their isotopic signature reflects the pre-existing crust that they intruded combined with new mantle input, with the most evolved magmas occurring in regions interpreted to have reworked craton margins (e.g. the Biranup Zone and Bunger Hills; Tucker 2018 and references therein).

The peak metamorphic conditions and post-peak down-temperature $\mathrm{P}-\mathrm{T}$ path recorded by the Bunger Hills are consistent with equivalent-aged high-temperature metamorphism in other parts of the orogen (Fig. 5). Magmatism and metamorphism between c. 1220 and $1130 \mathrm{Ma}$ were independent of the spatial extent of $c$. 1345-1260 Ma tectonothermal events (Tucker 2018), suggesting that the thermal driver for the younger event was not the same as the former, was independent of pre-existing crustal character and was considerably more regional. Metamorphism between $c .1220$ and $1130 \mathrm{Ma}$ was characterized by remarkably similar high to ultrahigh apparent thermal gradients (Fig. 5), which is suggestive of an orogen-wide thermal driver and regional geodynamic control on metamorphism. Differences in absolute P-T probably reflect different mid-lower crustal expressions of metamorphism within the same orogenic system (Fig. 5; Tucker 2018) and the local effects of advective heating due to the syn-metamorphic emplacement of magmas (e.g. Windmill Islands; Morrissey et al. 2017a). Peak pressures are low to moderate and differences in metamorphic pressure are smaller than differences in temperature (Fig. 5; Tucker 2018), suggesting that c. 1220-1130 Ma metamorphism and magmatism were associated with extension rather than tectonic thickening. 


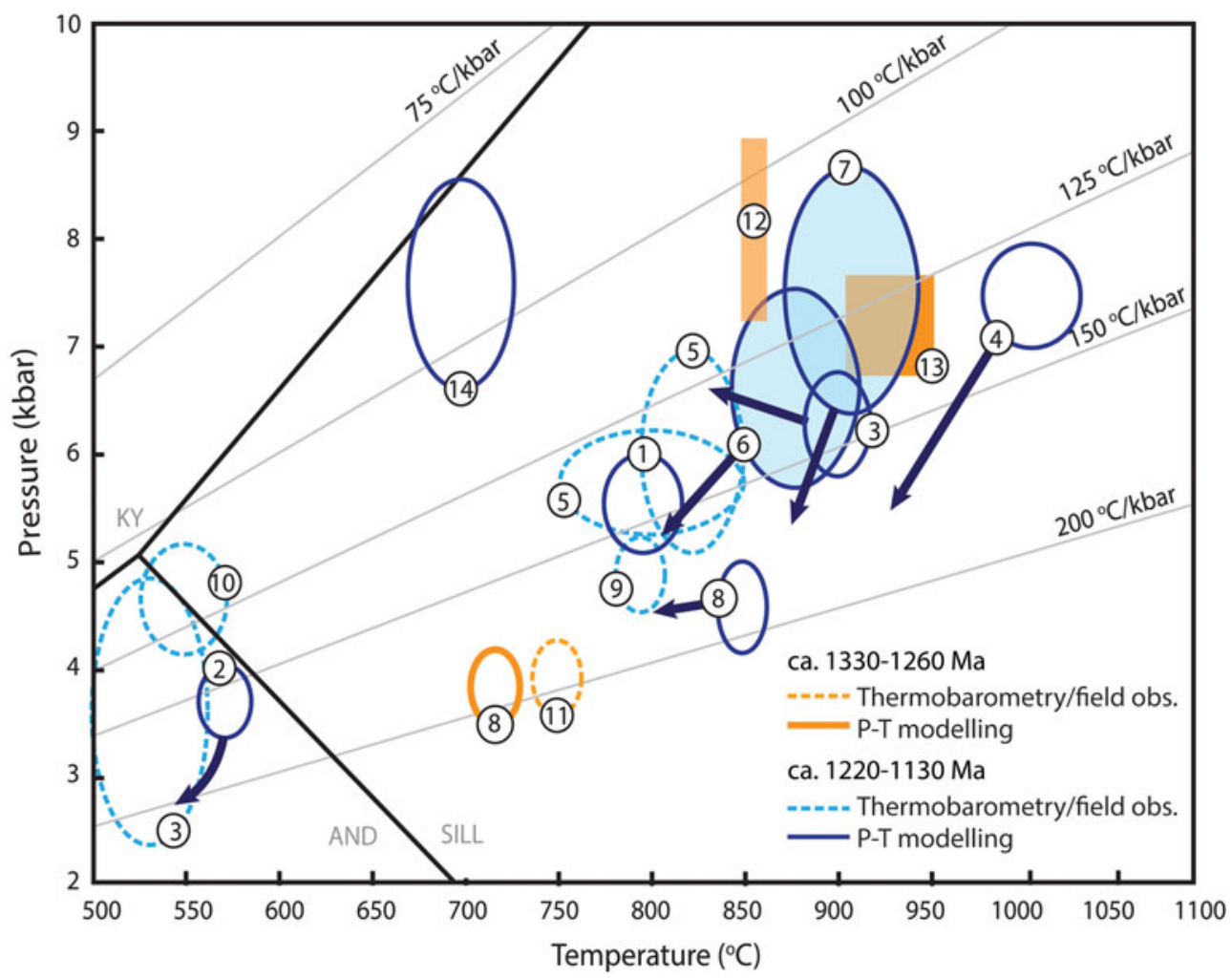

Fig. 5. Summarised pressure-temperature ( $\mathrm{P}-\mathrm{T})$ constraints for Stage 1 (orange) and Stage 2 (blue) metamorphism in the MusgraveAlbany-Fraser-Wilkes Orogen. Data from the Bunger Hills and Highjump Archipelago are indicated by blue filled ellipses. Dashed lines indicate that $\mathrm{P}-\mathrm{T}$ constraints were obtained by conventional thermobarometry or estimated from field observations; all other constraints are based on forward phase equilibria modelling. Figure adapted from Tucker (2018). Data are from: 1) Southern Aileron/ North Warumpi Province (Wong et al. 2015), 2) East Warumpi Province (Morrissey et al. 2011), 3) East Musgrave Inlier, Kalamurta Gneiss (Tucker et al. 2015) and Mulga Park andalusite-bearing rocks (unpublished), 4) West Musgrave Inlier (Walsh et al. 2015),

5) Biranup Zone (Bordorkos \& Clark 2004), 6) Bunger Hills (Tucker et al. 2017), 7) Highjump Archipelago (Tucker \& Hand 2016), 8) Windmill Islands (Morrissey et al. 2017a), 9) Madura Province (Salisbury Gneiss; Clark et al. 2000), 10) East Nornalup Zone (Ragged Basin; Clark et al. 2000), 11) East Nornalup Zone (Malcolm Metamorphics; Clark et al. 2000), 12) Fraser Zone (Arid Basin; Clark et al. 2014), 13) Fraser Zone (gabbro; Glasson et al. 2019) and 14) Barren Basin (Fly Dam Formation; Kirkland et al. 2016). $\mathrm{AND}=$ andalusite, $\mathrm{KY}=$ kyanite, $\mathrm{SILL}=$ sillimanite.

This interpretation is supported by the consistent shallow decompressive to quasi-isobaric post-peak evolutions orogen-wide (Fig. 5).

Tucker (2018) surmised that regional, long-lived and anomalously high thermal gradients during metamorphism, $\mathrm{P}-\mathrm{T}$ evidence for thin crust and large-volume crustal melting with a significant mantle source contribution require unusually high heat flow and can be explained by mantle lithosphere removal, specifically delamination. The specific mechanism that initiated orogen-wide delamination, however, is presently ambiguous, but it is inferred to relate to the anatomy of the final craton convergence between the two Mesoproterozoic tectonothermal events (Tucker 2018) in which all terranes of the MAFWO were joined and thus recorded a united c. 1220-1130 Ma thermal evolution (e.g. Clark et al. 2000, Fitzsimons 2003, Boger 2011, Tucker 2018 and references therein).

\section{Gondwanan assembly and Pan-African tectonothermal events}

Initial models for the late Neoproterozoic-early Cambrian assembly of Gondwana interpret East Antarctica, parts of east Africa, India and Australia to have remained as a coherent crustal block since the breakup of Rodinia, with these continents linked by $c$. 1300-900 Ma orogenic belts (e.g. Hoffman 1991, Moores 1991, Meert \& Van Der Voo 1997). Fitzsimons (2000) subsequently identified that Rodinian orogenesis occurred at 1330-1130 and 980-900 Ma in Wilkes Land and the Rayner Complex in East Antarctica, respectively, and considered these two age populations to be indicative of Indo-Antarctic and Australo-Antarctic crust. These early interpretations were reinforced by Mikhalsky et al. (2015b), who identified abundant 980-920 Ma metamorphic zircon in in situ basement rocks from Mount Brown and Mirny Station 
and xenocrystic zircon in Quaternary lavas from Gaussberg volcano. Daczko et al. (2018) compiled previously published detrital zircon data from offshore sediments and highlighted contrasting age populations between Prydz Bay (980-900 Ma) and the Wilkes Land coast (1190-1140 Ma), which is consistent with the known onshore geology. Mulder et al. (2019) also demonstrated that Indo- and Australo-Antarctic crust have distinct $\mathrm{Pb}$ isotope signatures and hence evolved independently with respect to their tectonothermal histories, prior to being juxtaposed.

Furthermore, Daczko et al. (2018) identified that offshore detritus from Prydz Bay and the Denman Glacier coastline recorded ages of $c$. 550-500 Ma, supporting the record of Cambrian high-grade metamorphism and felsic magmatism from rare exposures in this region (e.g. Sheraton et al. 1992, Dirks \& Wilson 1995, Carson et al. 1996, Fitzsimons et al. 1997, Harley 2003, Mikhalsky et al. 2013, 2015b, Gardner et al. 2015, Morrissey et al. 2016) and dredge samples from the Batavia and Gulden Draak knolls and Naturaliste Plateau that reconstruct close to this location in Gondwanan East Antarctica (Halpin et al. 2008, 2017, Gardner et al. 2015). Notably, there is a comparative lack of Cambrian ages in Wilkes Land and the Rayner Complex to the east and west of these regions, respectively.

The differences in protolith age between Wilkes Land and the Rayner Complex (excluding locally identified 1380-1020 Ma orthogneiss in the Rayner Complex; e.g. Liu et al. 2009, Halpin et al. 2012), evidence for anorogenic magmatism approximately between the two and $c$. 700-750 Ma palaeopoles from India (Torsvik et al. 2001, Gregory et al. 2009) and Australia (Wingate \& Giddings 2000) suggest that crust with Indo- and Australo-Antarctic affinity collided during the Ediacaran-Cambrian (Gondwana assembly; e.g. Fitzsimons 2000, 2003, Wilson et al. 2001, Meert 2003, Boger 2011, Aitken et al. 2014, 2016, Halpin et al. 2017, Mulder et al. 2019). The suture is inferred to bisect East Antarctica, immediately west of the Bunger Hills, approximately beneath the Denman and/or Scott glaciers (Fitzsimons 2003, Meert 2003, Boger 2011, Harley et al. 2013, Aitken et al. 2014), although its exact position and geometry are unclear as it is concealed by the Antarctic ice sheet (see Fig. 1b). Furthermore, the specific timing of collision is not well constrained from palaeomagnetic data (Halpin et al. 2017).

Using geophysical data, Aitken et al. (2014) suggested that the Gondwanan suture intersected the coast near Scott Glacier (Fig. 1b) and that its position was defined by prominent changes in density and subglacial topography and the truncation of magnetic features, which trend NE in Australo-Antarctica and SSE in Indo-Antarctica. Gardner et al. (2015) subsequently proposed that the suture was located $\sim 50 \mathrm{~km}$ further west, near the Denman Glacier, whilst Maritati et al. (2016) suggested that it passed through Chugunov Island (Fig. 1b). Using $\mathrm{U}-\mathrm{Pb}$ ages of offshore detritus along the East Antarctic coast as a proxy for the poorly exposed subglacial crust and new geochronology from inland exposures, Daczko et al. (2018) demonstrated that rocks on both sides of all previously proposed sutures in the Denman-Scott Glacier area have Australo-Antarctic affinities, and they alternatively suggested that the suture was located further west, within a $\sim 250 \mathrm{~km}$ stretch of coastline between Mirny and Cape Charcot. Specifically, Daczko et al. (2018) suggested the terrane boundary to be one of the geophysical lineaments east of Mirny Station identified by Aitken et al. (2014), which they term the Mirny Fault (Fig. 1b). Further support for the juxtaposition of Indo- and Australo-Antarctic crust along the Mirny Fault (Daczko et al. 2018) comes from detrital feldspar, zircon and monazite isotopic data from offshore Holocene sediments near Mirny Station that were sourced locally from crust either side of the Mirny Fault and include contributions from both Indo- and Australo-Antarctic crust (Mulder et al. 2019).

The suture was initially interpreted as a collision zone between Indo-Antarctic and Australo-Antarctic terranes (e.g. Fitzsimons 2003, Boger \& Miller 2004, Collins \& Pisarevsky 2005, Boger 2011, Harley et al. 2013); however, this tectonic interpretation was based on limited coastal exposures and is thus speculative. Syenitic to granitic magmatism (c. $516 \mathrm{Ma}$ ) between Mirny and the Bunger Hills is interpreted to be post-orogenic or anorogeneic (Sheraton et al. 1992). Hf isotope compositions of zircon from the Cambrian granites are also suggestive of reworking of Archean $(>2.9 \mathrm{Ga}$ ) crust, possibly from the Yilgarn Craton, Cape Charcot, Obruchev Hills or Bunger Hills, with little juvenile input, which is inconsistent with their emplacement in an arc environment (i.e. subduction zone) and more consistent with strike-slip tectonics (Halpin et al. 2017). This interpretation is consistent with some recent palaeogeographic reconstructions that juxtapose Indo- and Australo-Antarctic terranes in Gondwana along a sinistral strike-slip margin (Gregory et al. 2009, Li et al. 2013), the inferred reactivation direction of basement faults in Mesozoic west Australian basins during Gondwanan breakup (Hall et al. 2013), Cambrian strike-slip kinematics near the Darling Fault (Beeson et al. 1988, Fitzsimons 2003) and the approximately east to west trend of $c$. $500 \mathrm{Ma}$ mafic dykes in the Bunger Hills that imply and approximately north to south extension (Sheraton et al. 1990) and is thus consistent with sinistral strike-slip movement along possible terrane boundaries to the west of the Bunger Hills (e.g. Aitken et al. 2014, Halpin et al. 2017, Daczko et al. 2018, Mulder et al. 2019). The record of Cambrian metamorphism and deformation in East Antarctica 
between the Rayner Complex and Wilkes Land may therefore be suggestive of a sinistral strike-slip zone that is $>500 \mathrm{~km}$ wide and $>2000 \mathrm{~km}$ long (Halpin et al. 2017). Alternatively, Boger and Wilson (2005) report evidence for Cambrian compressional orogenesis in the Prydz Bay region, suggesting that this segment of the Gondwanan Orogen may represent a zone of high-angle convergence between Indo- and Australo-Antarctica (i.e. an accretionary or collisional setting). Mulder et al. (2019) present one possible interpretation of the architecture of the Kuunga Orogen between Mirny and Prydz Bay, suggesting that East Gondwanan assembly involved dominantly strike-slip motion in the Mirny region coupled with high-angle convergence between Indo-Antarctica and Australo-Antarctica further west (see also Fitzsimons 2003, Boger 2011, Mikhalsky et al. 2015b). Importantly, there is a lack of Cambrian compressional deformation, metamorphism and subduction-related magmatism in the Bunger Hills region, suggesting that this was not the site of orthogonal collision between Indo- and Australo-Antarctica.

The exact timing of the Gondwanan collision of Indo- and Australo-Antarctica remains unresolved as the current palaeopoles do not provide accurate age constraints. It is also possible that Cambrian zircon in the offshore detritus relates to post-amalgamation granite magmatism as the magmatic rocks are undeformed (Halpin et al. 2017). Regardless, collision is inferred to have occurred between c. 550-500 Ma (granite crystallization and metamorphic ages; e.g. Corvino et al. 2008, Liu 2009, Liu et al. 2009, Gardner et al. 2015) and c. $630-620 \mathrm{Ma}$ (biotite recrystallization ages from the south-west Yilgarn Craton; Lu et al. 2015).

\section{The Bunger Hills and East Gondwana breakup}

Post Pan-African tectonism, the Bunger Hills remained in a key position at the triple junction of Greater India, Australia and East Antarctica (e.g. Fitzsimons 2003). Therefore, although the primary scope of this review is the Neoarchean-Cambrian evolution of the Bunger Hills region, we briefly highlight the aerogeophysical data of Aitken et al. (2014) and Maritati et al. (2016), who identified the inferred Mesozoic Knox Rift. The Knox Rift overprints the Precambrian basement in Wilkes Land, is bounded by the NNE-trending Conger and Scott faults and is inferred to contain a deep sedimentary basin segmented by NNW-trending faults (Fig. 1). Maritati et al. (2016) suggested the Knox Rift to be a failed transtensional rift that developed during Permian-Triassic global reorganization of East Gondwana and subsequent Jurassic-Cretaceous rifting of Greater India from East Antarctica. Geophysical constraints from the Knox Rift have refined the position of Australia and East Antarctica in full-fit Gonwanan reconstructions, as it is inferred to be a conjugate to the Perth Basin and offshore Mentell Basin of Western Australia (Maritati et al. 2016).

\section{Acknowledgements}

The authors wish to acknowledge support from the Australian Antarctic Division (Project 4191) for undertaking fieldwork in the Bunger Hills in the Australian-Antarctic 2014-2015 summer season. A. Maritati and an anonymous reviewer are thanked for their constructive and insightful suggestions and comments on the manuscript. A. Maritati is also thanked for providing a spatial dataset for constructing Fig. 1 .

\section{Author contributions}

NMT was primarily responsible for the literature review, data collation and preparation of the manuscript and figures. All authors were involved in the original paper concept and design. All authors undertook fieldwork in the Australian-Antarctic 2014-2015 summer season, which formed the basis for this review.

\section{References}

Aitken, A.R.A., Betts, P.G., Young, D.A., Blankenship, D.D., Roberts, J.L. \& Siegert, M.J. 2016. The Australo-Antarctic Columbia to Gondwana transition. Gondwana Research, 29, 136-152. Aitken, A.R.A., Young, D.A., Ferraccioli, F., Betts, P.G., Greenbaum, J.S., Richter, T.G., et al. 2014. The subglacial geology of Wilkes Land, East Antarctica. Geophysical Research Letters, 41, 10.1002/2014GL059405.

Alexeev, N.L., Zinger, T.F. \& Kapitonov, I.N. 2011. Age of charnockitic magmatism from the Obruchev Hills, Banger-Denman area (East Antarctica). Doklady Earth Sciences, 440, 1233.

Beeson, J., Delor, C.P. \& Harris, L.B. 1988. A structural and metamorphic traverse across the Albany Mobile Belt, Western Australia. Precambrian Research, 40, 117-136.

Black, L.P., Sheraton, J.W., Tingey, R.J. \& McCulloch, M.T. 1992. New U-Pb zircon ages from the Denman Glacier area, East Antarctica, and their significance for Gondwana reconstruction. Antarctic Science, 4, 447-460.

Bodorkos, S. \& CLARK, D.J. 2004. Evolution of a crustal-scale transpressive shear zone in the Albany-Fraser Orogen, SW Australia: 1. $P-T$ conditions of Mesoproterozoic metamorphism in the Coramup Gneiss. Journal of Metamorphic Geology, 22, 691-711.

Boger, S.D. 2011. Antarctica - before and after Gondwana. Gondwana Research, 19, 335-371.

Boger, S. \& Miller, J.M. 2004. Terminal suturing of Gondwana and the onset of the Ross-Delamerian Orogeny: the cause and effect of an Early Cambrian reconfiguration of plate motions. Earth and Planetary Science Letters, 219, 35-48.

Boger, S. \& Wilson, C. 2005. Early Cambrian crustal shortening and a clockwise P-T-t path from the southern Prince Charles Mountains, East Antarctica: implications for the formation of Gondwana. Journal of Metamorphic Geology, 23, 603-623.

Carson, C.J., Fanning, C.M. \& Wilson, C.J.L. 1996. Timing of the progress granite, Larsemann hills: additional evidence for early 
Palaeozoic orogenesis within the east Antarctic Shield and implications for Gondwana assembly. Australian Journal of Earth Sciences, 43, 539-553.

Clark, C., Kirkland, C.L., Spaggiari, C.V., Oorschot, C., Wingate, M.T.D. \& TaYlor, R.J. 2014. Proterozoic granulite formation driven by mafic magmatism: an example from the Fraser Range Metamorphics, Western Australia. Precambrian Research, 240, 1-21.

Clark, D.J., Hensen, B.J. \& Kinny, P.D. 2000. Geochronological constraints for a two-stage history of the Albany-Fraser Orogen, Western Australia. Precambrian Research, 102, 155-183.

Clarke, G.L., Sun, S.S. \& White, R.W. 1995. Grenville-age belts and associated older terranes in Australia and Antarctica. AGSO Journal of Australian Geology \& Geophysics, 16, 25-39.

Collins, A.S. \& Pisarevsky, S.A. 2005. Amalgamating eastern Gondwana: the evolution of the Circum-Indian Orogens. Earth-Science Reviews, 71, 229-270.

Corvino, A.F., Boger, S.D., Henjes-Kunst, F., Wilson, C.J.L. \& Fitzsimons, I.C.W. 2008. Superimposed tectonic events at $2450 \mathrm{Ma}$, $2100 \mathrm{Ma}, 900 \mathrm{Ma}$ and $500 \mathrm{Ma}$ in the North Mawson Escarpment, Antarctic Prince Charles Mountains. Precambrian Research, 167, 281-302.

Daczko, N.R., Halpin, J.A., Fitzsimons, I.C. \& Whittaker, J.M. 2018. A cryptic Gondwana-forming orogen located in Antarctica. Scientific Reports, 8, 8371.

Ding, P., \& JAMEs, P. 1991. Structural evolution of the Bunger Hills area of East Antarctica. In Thomson, M.R.A., ed. Geological evolution of Antarctica. Cambridge: Cambridge University Press, 13-18.

DiRKS, P.H.G.M. \& WILSON, C.J.L. 1995. Crustal evolution of the East Antarctic mobile belt in Prydz Bay: continental collision at $500 \mathrm{Ma}$ ? Precambrian Research, 75, 189-207.

Fitzsimons, I.C.W. 2000. Grenville-age basement provinces in East Antarctica: evidence for three separate collisional orogens. Geology, 28, 879-882.

Fitzsimons, I. 2003. Proterozoic basement provinces of southern and southwestern Australia, and their correlation with Antarctica. In Yoshida, M., Windley, B.F. \& Dasgupta, S., eds. Proterozoic East Gondwana; supercontinent assembly and breakup. Special Publication of the Geological Society of London, No. 206, 93-130.

Fitzsimons, I.C.W., Kinny, P.D. \& Harley, S.L. 1997. Two stages of zircon and monazite growth in anatectic leucogneiss: SHRIMP constraints on the duration and intensity of Pan-African metamorphism in Prydz Bay, East Antarctica. Terra Nova, 9, 47-51.

Gardner, R.L., Daczko, N.R., Halpin, J.A. \& Whittaker, J.M. 2015. Discovery of a microcontinent (Gulden Draak Knoll) offshore Western Australia: implications for East Gondwana reconstructions. Gondwana Research, 28, 1019-1031.

Glasson, K.J., Johnson, T.E., Kirkland, C.L., Gardiner, N.J., Clark, C., Blereau, E., et al. 2019. A window into an ancient backarc? The magmatic and metamorphic history of the Fraser Zone, Western Australia. Precambrian Research, 323, 55-69.

Gregory, L.C., Meert, J.G., Bingen, B., Pandit, M.K. \& Torsvik, T.H. 2009. Paleomagnetism and geochronology of the Malani Igneous Suite, northwest India: implications for the configuration of Rodinia and the assembly of Gondwana. Precambrian Research, 170, 13-26.

Hall, L., Gibbons, A., Bernardel, G., Whittaker, J., Nicholson, C., Rollet, N., et al. 2013. Structural architecture of Australia's southwest continental margin and implications for Early Cretaceous basin evolution. In Moss, S.J., Keep, M. \& Petroleum Exploration Society of Australia. Western Australian Branch, eds. West Australian Basins Symposium 2013 Proceedings: WABS 2013, 18-21 August 2013, Perth Convention Centre, Western Australia. Perth: Petroleum Exploration Society of Australia, 2-20.

Halpin, J.A., Daczko, N.R., Kobler, M.E. \& Whittaker, J.M. 2017. Strike-slip tectonics during the Neoproterozoic-Cambrian assembly of East Gondwana: evidence from a newly discovered microcontinent in the Indian Ocean (Batavia Knoll). Gondwana Research, 51, 137-148.

Halpin, J.A., Daczko, N.R., Milan, L.A. \& Clarke, G.L. 2012. Decoding near-concordant $\mathrm{U}-\mathrm{Pb}$ zircon ages spanning several hundred million years: recrystallisation, metamictisation or diffusion? Contributions to Mineralogy and Petrology, 163, 67-85.

Halpin, J.A., Crawford, A.J., Direen, N.G., Coffin, M.F., Forbed, C.J. \& Borissova, I. 2008. Naturaliste Plateau, offshore Western Australia: a submarine window into Gondwana assembly and breakup. Geology, 36, 807-810.

Harley, S.L. 2003. Archaean-Cambrian crustal development of East Antarctica: metamorphic characteristics and tectonic implications. In Yoshida, M., Windley, B.F. \& Dasgupta, S., eds. Proterozoic East Gondwana; supercontinent assembly and breakup. Special Publication of the Geological Society of London, No. 206, 203-230.

Harley, S.L., Fitzsimons, I.C.W. \& Zhao, Y. 2013. Antarctica and supercontinent evolution: historical perspectives, recent advances and unresolved issues. In Harley, S.L., Fitzsimons, I.C.W. \& Zhao, Y., eds. Antarctica and supercontinent evolution. Special Publication of the Geological Society of London, No. 383, 1-34.

HARrIs, L.B. 1995. Correlations between the Albany, Fraser and Darling mobile belts of Western Australia and Lirnyy to Windmill Islands in the East Antarctic Shield: implications for Proterozoic Gondwanaland reconstructions. In Yoshida, M. \& SANTosh, M., eds. India and Antarctica during the Precambrian, Memoirs of the Geological Society of India. Bangalore: Geological Society of India, $47-72$.

Hoffman, P.F. 1991. Did the breakout of Laurentia turn Gondwanaland inside-out? Science, 252, 1409-1412.

Howard, H.M., Smithies, R.H., Kirkland, C.L., Kelsey, D.E., Aitken, A., Wingate, M.T.D., et al. 2015. The burning heart - the Proterozoic geology and geological evolution of the west Musgrave Region, central Australia. Gondwana Research, 27, 64-94.

Kirkland, C.L., Smithies, R.H. \& Spaggiari, C.V. 2015. Foreign contemporaries - unravelling disparate isotopic signatures from Mesoproterozoic Central and Western Australia. Precambrian Research, 265, 218-231.

Kirkland, C.L., Spaggiari, C.V., Smithies, R.H. \& Wingate, M.T.D. 2014. Cryptic progeny of craton margins: geochronology and isotope geology of the Albany-Fraser Orogen, with implications for evolution of the Tropicana Zone. In Spaggiari, C.V. \& Tyler, I.M. eds. Albany-Fraser Orogen Seismic and Magnetotelluric (MT) Workshop 2014: Extended Abstracts. Perth: Geological Survey of Western Australia, 81-92.

Kirkland, C., Smithies, R., Spaggiari, C., Wingate, M., de Gromard, R.Q., Clark, C., et al. 2017. Proterozoic crustal evolution of the Eucla basement, Australia: implications for destruction of oceanic crust during emergence of Nuna. Lithos, 278, $427-444$.

Kirkland, C.L., Spaggiari, C.V., Johnson, T.E., Smithies, R.H., DANIŠí, M., Evans, N., et al. 2016. Grain size matters: implications for element and isotopic mobility in titanite. Precambrian Research, 278, 283-302.

Kirkland, C.L., Spaggiari, C.V., Pawley, M.J., Wingate, M.T.D., Smithies, R.H., Howard, H.M., et al. 2011. On the edge: U-Pb, $\mathrm{Lu}-\mathrm{Hf}$, and $\mathrm{Sm}-\mathrm{Nd}$ data suggests reworking of the Yilgarn craton margin during formation of the Albany-Fraser Orogen. Precambrian Research, 187, 223-247.

Li, Z.-X., Evans, D.A. \& Halverson, G.P. 2013. Neoproterozoic glaciations in a revised global palaeogeography from the breakup of Rodinia to the assembly of Gondwanaland. Sedimentary Geology, 294, 219-232.

Liv, X. 2009. Polymetamorphism of the Prydz Belt, East Antarctica: implications for the reconstruction of the Rodinia and Gondwana supercontinents. Acta Petrologica Sinica, 25, 1808-1818. 
Liv, X., Zhao, Y., Song, B., LiU, J. \& CuI, J. 2009. SHRIMP U-Pb zircon geochronology of high-grade rocks and charnockites from the eastern Amery Ice Shelf and southwestern Prydz Bay, East Antarctica: constraints on Late Mesoproterozoic to Cambrian tectonothermal events related to supercontinent assembly. Gondwana Research, 16, $342-361$.

Liv, Y., Li, Z.-X., Pisarevsky, S.A., Kirscher, U., Mitchell, R.N., StARK, J.C., et al. 2018. First Precambrian palaeomagnetic data from the Mawson Craton (East Antarctica) and tectonic implications. Scientific Reports, 8, 16403.

Lu, S., Phillips, D., Kohn, B., Gleadow, A. \& Matchan, E. 2015. Thermotectonic evolution of the western margin of the Yilgarn craton, Western Australia: new insights from ${ }^{40} \mathrm{Ar} /{ }^{39} \mathrm{Ar}$ analysis of muscovite and biotite. Precambrian Research, 270, 139-154.

Maritati, A., Halpin, J.A., Whittaker, J.M. \& Daczko, N.R. 2019. Fingerprinting proterozoic Bedrock in interior Wilkes Land, East Antarctica. Scientific Reports, 9, 10192.

Maritati, A., Aitken, A.R.A., Young, D.A., Roberts, J.L., Blankenship, D.D. \& Siegert, M.J. 2016. The tectonic development and erosion of the Knox Subglacial Sedimentary Basin, East Antarctica. Geophysical Research Letters, 43, 10.1002/2016gl071063.

Meert, J.G. 2003. A synopsis of events related to the assembly of eastern Gondwana. Tectonophysics, 362, 1-40.

Meert, J.G. \& VAn Der Voo, R. 1997. The assembly of Gondwana 800-550 Ma. Journal of Geodynamics, 23, 223-235.

Mikhalsky, E.V., Belyatsky, B.V. \& Presnyakov, S.L. 2015a. New U-Pb zircon age data from the Bunger Hills-Denman Glacier area: prominent orogeny at $c a$. 1190-1140 Ma and possible link to the Mawson palaeocontinent [abstract]. In MoHAN, R., RavichandRAN, M., Pant, N.C. \& TANDon, S.K., eds. XII International Symposium on Antarctic Earth Sciences, 13-17 July 2015, Goa, India. Cambridge: Scientific Committee on Antarctic Research, 92-93.

Mikhalsky, E.V., Belyatsky, B.V., Presnyakov, S.L., Skublov, S.G., Kovach, V.P., Rodionov, N.V., et al. 2015b. The geological composition of the hidden Wilhelm II Land in East Antarctica: SHRIMP zircon, $\mathrm{Nd}$ isotopic and geochemical studies with implications for Proterozoic supercontinent reconstructions. Precambrian Research, 258, 171-185.

Mikhalsky, E., Sheraton, J., Kudriavtsev, I., Sergeev, S., Kovach, V., Kamenev, I., et al. 2013. The Mesoproterozoic Rayner Province in the Lambert Glacier area: its age, origin, isotopic structure and implications for Australia-Antarctica correlations. In HARLEY S.L., Fitzsimons, I.C.W. \& Zhaо, Y., eds. Antarctica and supercontinent evolution. Special Publication of the Geological Society of London, No. 383, 35-57.

MoORES, E.M. 1991. Southwest U.S.-East Antarctic (SWEAT) connection: a hypothesis. Geology, 19, 425-428.

Morrissey, L.J., Hand, M., \& Kelsey, D.E. 2017a. A curious case of agreement between conventional thermobarometry and phase equilibria modelling in granulites: new constraints on $\mathrm{P}-\mathrm{T}$ estimates in the Antarctica segment of the Musgrave-Albany-Fraser-Wilkes Orogen. Journal of Metamorphic Geology, 35, 1023-1050.

Morrissey, L.J., Hand, M., Kelsey, D.E. \& Wade, B.P. 2016. Cambrian high-temperature reworking of the Rayner-Eastern Ghats terrane: constraints from the northern Prince Charles Mountains Region, East Antarctica. Journal of Petrology, 57, 53-92.

Morrissey, L., Payne, J.L., Kelsey, D.E. \& Hand, M. 2011. Grenvillian-aged reworking in the North Australian Craton, central Australia: constraints from geochronology and modelled phase equilibria. Precambrian Research, 191, 141-165.

Morrissey, L.J., Payne, J.L., Hand, M., Clark, C., Taylor, R., Kirkland, C.L., \& KYlander-Clark, A. 2017b. Linking the Windmill Islands, East Antarctica and the Albany-Fraser Orogen: insights from $\mathrm{U}-\mathrm{Pb}$ zircon geochronology and $\mathrm{Hf}$ isotopes. Precambrian Research, 293, 131-149.

Mulder, J.A., Halpin, J.A., Daczko, N.R., Orth, K., Meffre, S., Thompson, J.M., et al. 2019. A multiproxy provenance approach to uncovering the assembly of East Gondwana in Antarctica. Geology, 47, 645-649.

Post, N.J. 2000. Unravelling Gondwana fragments: an integrated structural, isotopic and petrographic investigation of the Windmill Islands, Antarctica. PhD thesis, University of New South Wales, 382 pp. [Unpublished].

Ravich, M.G.E., Klimov, L. \& Solov'ev, D. 1968. The Pre-Cambrian of East Antarctica. Israel Program for Scientific Translation. Springfield, VA: US Department of Commerce, Clearinghouse for Federal Scientific and Technical Information, $475 \mathrm{pp}$

Sheraton, J.W., Black, L.P. \& Tindle, A.G. 1992. Petrogenesis of plutonic rocks in a Proterozoic granulite-facies terrane - the Bunger Hills, East Antarctica. Chemical Geology, 97, 163-198.

Sheraton, J.W., Black, L.P., McCulloch, M.T. \& Oliver, R.L. 1990. Age and origin of a compositionally varied mafic dyke swarm in the Bunger Hills, East Antarctica. Chemical Geology, 85, 215-246.

Sheraton, J.W., Tingey, R.J., Black, L.P. \& Oliver, R.L. 1993. Geology of the Bunger Hills area, Antarctica: implications for Gondwana correlations. Antarctic Science, 5, 85-102.

Sheraton, J.W., Tingey, R., Oliver, R. \& Black, L. 1995. Geology of the Bunger Hills-Denman Glacier Region, East Antarctica. Canberra: Australian Government Publishing Service.

Smithies, R.H., Spaggiari, C.V. \& Kirkland, C.L. 2015b. Building the crust of the Albany-Fraser Orogen: constraints from granite geochemistry. Perth: Geological Survey of Western Australia, $49 \mathrm{pp}$.

Smithies, R.H., Howard, H.M., Evins, P.M., Kirkland, C.L., Kelsey, D.E., Hand, M., et al. 2011. High-temperature granite magmatism, crust-mantle interaction and the mesoproterozoic intracontinental evolution of the Musgrave Province, central Australia. Journal of Petrology, 52, 931-958.

Smithies, R.H., Kirkland, C.L., Korhonen, F.J., Aitken, A.R.A., Howard, H.M., Maier, W.D., et al. 2015a. The Mesoproterozoic thermal evolution of the Musgrave Province in central Australia plume vs. the geological record. Gondwana Research, 27, 1419-1429.

Spaggiari, C.V. \& Smithies, R.H. 2015. Eucla Basement Stratigraphic Drilling Results Release Workshop: Extended Abstracts. Perth: Geological Survey of Western Australia, $70 \mathrm{pp}$.

Spaggiari, C.V. \& Tyler, I.M. 2014. Albany-Fraser Orogen Seismic and Magnetotelluric (MT) Workshop 2014: Extended Abstracts. Perth: Geological Survey of Western Australia, 165 pp.

Spaggiari, C.V., Kirkland, C.L., Smithies, R.H., Wingate, M.T.D. \& Belousova, E.A. 2015. Transformation of an Archean craton margin during Proterozoic basin formation and magmatism: the AlbanyFraser Orogen, Western Australia. Precambrian Research, 266, 440-466.

Spaggiari, C.V., Smithies, R.H., Kirkland, C.L., Wingate, M.T., EnGLAND, R.N. \& Lu, Y.-J. 2018. Buried but preserved: the Proterozoic Arubiddy Ophiolite, Madura Province, Western Australia. Precambrian Research, 317, 137-158.

Stark, J.C., Wang, X.-C., Li, Z.-X., Rasmussen, B., Sheppard, S., $\mathrm{ZI}$, J.-W., et al. 2018. In situ U-Pb geochronology and geochemistry of a $1.13 \mathrm{Ga}$ mafic dyke suite at Bunger Hills, East Antarctica: the end of the Albany-Fraser Orogeny. Precambrian Research, 310, 76-92.

Stüwe, K. \& Powell, R. 1989. Metamorphic evolution of the Bunger Hills, East Antarctica: evidence for substantial post-metamorphic peak compression with minimal cooling in a Proterozoic orogenic event. Journal of Metamorphic Geology, 7, 449-464.

Stüwe, K. \& WiLSON, C.J.L. 1990. Interaction between deformation and charnockite emplacement in the Bunger Hills, East Antarctica. Journal of Structural Geology, 12, 767-783.

Torsvik, T., Carter, L., Ashwal, L., Bhushan, S., Pandit, M. \& JAMTVEIT, B. 2001. Rodinia refined or obscured: palaeomagnetism of the Malani igneous suite (NW India). Precambrian Research, 108, 319-333. 
Tucker, N. 2018. Metamorphic and crustal evolution of AustralianAntarctic proterozoic margins. $\mathrm{PhD}$ thesis, University of Adelaide, 383 pp. [Unpublished].

TUCKER, N.M. \& HAND, M. 2016. New constraints on metamorphism in the Highjump Archipelago, East Antarctica. Antarctic Science, 28, 487-503.

Tucker, N.M., Hand, M., Kelsey, D.E. \& Dutch, R.A. 2015. A duality of timescales: short-lived ultrahigh temperature metamorphism preserving a long-lived monazite growth history in the Grenvillian Musgrave-Albany-Fraser Orogen. Precambrian Research, 264, 204-234.

Tucker, N.M., Hand, M., Kelsey, D.E., Taylor, R., Clark, C. \& PAYNE, J.L. 2018. A tripartite approach to unearthing the duration of high temperature conditions versus peak metamorphism: an example from the Bunger Hills, East Antarctica. Precambrian Research, 314, 194-220.

Tucker, N.M., Payne, J.L., Clark, C., Hand, M., Taylor, R.J.M., Kylander-Clark, A.R.C., et al. 2017. Proterozoic reworking of Archean (Yilgarn) basement in the Bunger Hills, East Antarctica. Precambrian Research, 298(Suppl. C), 16-38.

Walsh, A.K., Kelsey, D.E., Kirkland, C.L., Hand, M., Smithies, R.H., CLARK, C., et al. 2015. P-T-t evolution of a large, long-lived, ultrahigh-temperature Grenvillian belt in central Australia. Gondwana Research, 28, 531-564.

White, L.T., Gibson, G.M. \& Lister, G.S. 2013. A reassessment of paleogeographic reconstructions of eastern Gondwana: bringing geology back into the equation. Gondwana Research, 24, 984-998.
Williams, S.E., Whittaker, J.M. \& Müller, R.D. 2011. Full-fit, palinspastic reconstruction of the conjugate Australian-Antarctic margins. Tectonics, 30, 10.1029/2011TC002912.

Williams, S.E., Whittaker, J.M., Halpin, J.A. \& Müller, R.D. 2018. Australian-Antarctic break up and seafloor spreading: balancing geological and geophysical constraints. Earth-Science Reviews, 188, $41-58$.

Wilson, C.J.L., Boger, S.D. \& Fanning, C.M. 2001. Early Paleozoic tectonism within the East Antarctic craton: the final suture between East and West Gondwana? Geology, 29, 463-466.

Wingate, M.T.D. \& Giddings, J.W. 2000. Age and palaeomagnetism of the Mundine Well dyke swarm, Western Australia: implications for an Australia-Laurentia connection at 755 Ma. Precambrian Research, 100, 335-357.

Wise, T.W., Pawley, M.J. \& Dutch, R.A. 2015. Preliminary interpretations from the 2015 Coompana aeromagnetic survey. MESA Journal, 79, 22-30.

Wong, B.L., Morrissey, L.J., Hand, M., Fields, C.E. \& Kelsey, D.E. 2015. Grenvillian-aged reworking of late Paleoproterozoic crust of the southern North Australian Craton, central Australia: implications for the assembly of Mesoproterozoic Australia. Precambrian Research, 270, 100-123.

Zhang, S., Zhao, Y., Liu, X., Liu, Y., Hou, K., Li, C. \& Ye, H. 2012. $\mathrm{U}-\mathrm{Pb}$ geochronology and geochemistry of the bedrocks and moraine sediments from the Windmill Islands: implications for Proterozoic evolution of East Antarctica. Precambrian Research, 206-207, 52-71. 